\title{
Mine Tailings Dams: Characteristics, Failure, Environmental Impacts, and Remediation
}

D. Kossoff ${ }^{1,2}$, W.E. Dubbin ${ }^{2}$, M.Alfredsson ${ }^{3}$, S.J. Edwards ${ }^{4}$, M.G. Macklin ${ }^{5,6}$ and K.A. HudsonEdwards $^{1 *}$

${ }^{1}$ Department of Earth and Planetary Sciences, Birkbeck, University of London, Malet St., London WC1E 7HX, UK. Email: *Corresponding author Tel: +44-(0)203-073-8030; Email: k.hudson-edwards@bbk.ac.uk

${ }^{2}$ Department of Earth Sciences, The Natural History Museum, Cromwell Road, London SW7 5BD, UK.

${ }^{3}$ School of Physical Sciences, Ingram Building, University of Kent, Canterbury CT2 7NH, UK

${ }^{4}$ Aon Benfield UCL Hazard Centre and Institute for Risk and Disaster Reduction Department of Earth Sciences, University College London, London WC1E 5BT, UK

${ }^{5}$ Centre for Catchment and Coastal Research and River Basin Dynamics and Hydrology Research Group, Department of Geography and Earth Sciences, Aberystwyth University, Ceredigion, SY23 3DB, UK.

${ }^{6}$ Innovative River Solutions, Institute of Agriculture and Environment, Massey University, Private Bag 11222, Palmerston North, 4442, New Zealand.

Submitted to: $\quad$ Applied Geochemistry

Date: $\quad$ May 2014

Keywords: $\quad$ mine tailings, dam, impoundment, failure, toxic, metal, metalloid, river sediment 


\begin{abstract}
On a global scale demand for the products of the extractive industries is ever increasing. Extraction of the targeted resource results in the concurrent production of a significant volume of waste material, including tailings, which are mixtures of crushed rock and processing fluids from mills, washeries or concentrators that remain after the extraction of economic metals, minerals, mineral fuels or coal. The volume of tailings is normally far in excess of the liberated resource, and the tailings often contain potentially hazardous contaminants. A priority for a reasonable and responsible mining organization must be to proactively isolate the tailings so as to forestall them from entering groundwaters, rivers, lakes and the wind. There is ample evidence that, should such tailings enter these environments they may contaminate food chains and drinking water. Furthermore, the tailings undergo physical and chemical change after they have been deposited. The chemical changes are most often a function of exposure to atmospheric oxidation and tends to make previously, perhaps safely held contaminants mobile and available. If the tailings are stored under water, contact with the atmosphere is substantially reduced, thereby forestalling oxygen-mediated chemical change. It is therefore accepted practice for tailings to be stored in isolated impoundments under water and behind dams. However, these dams frequently fail, releasing enormous quantities of tailings into river catchments. These accidents pose a serious threat to animal and human health and are of concern for extractive industries and the wider community. It is therefore of importance to understand the nature of the material held within these dams, what best safety practice is for these structures and, should the worst happen, what adverse effects such accidents might have on the wider environment and how these might be mitigated. This paper reviews these factors, covering the characteristics, types and magnitudes, environmental impacts, and remediation of mine tailings dam failures.
\end{abstract}




\section{Introduction}

Modern society could not function without the products of the extractive mining industries, which are vital components in, for example, aeroplanes, ceramics, computers, construction materials, metals and paint. On a global scale, the mining industry also provides direct employment to over 40 million people, and indirect support for c. 200-250 million people (allowing for employees' dependents; Azapagic, 2004). On a smaller, but nevertheless significant scale, mining companies provide local employment opportunities and social improvements, such as the provision of medical facilities, in areas where these might otherwise be limited (e.g., rural Australia; Cheshire, 2010). However, unregulated artisanal mining, particularly for gold, employs more than 10 million people worldwide and results in widespread environmental and health problems (Hilson, 2006).

The mining industry does, however, produce enormous volumes of waste. The amount of mine waste produced is of the same order of magnitude as that of fundamental Earth-shaping geological processes, some several thousand million tonnes per year (Fyfe, 1981; Förstner, 1999). The chief waste stream is tailings, which are often stored in impoundments behind dams, which can fail, with ensuing environmental, human health and economic impacts. In this paper we review the short-, medium- and longer-term effects of these impacts. To set the scene, we first describe the characteristics of tailings and of construction of tailings dams, and the common causes of their failure. We conclude with a discussion of currently-used remediation measures taken following dam failures, and recommendations for management of failures. This review will be of use to researchers studying the environmental effects of mine waste, and to mine managers and environmental scientists evaluating their impacts. 


\section{Tailings}

\subsection{Definition of tailings}

Tailings are mixtures of crushed rock and processing fluids from mills, washeries or concentrators that remain after the extraction of economic metals, minerals, mineral fuels or coal from the mine resource (e.g., Fig. 1a; Hudson-Edwards et al., 2001; Younger and Wolkersdorfer, 2004; Lottermoser, 2007). The word 'tailings' is generic as it describes the by-product of several extractive industries, including those for aluminium, coal, oil sands, uranium and precious and base metals.

The ratio of tailings to concentrate is commonly very high, generally around 200:1 (Lottermoser, 2007). Moreover, as the point of peak metal production is surpassed, the extraction of lower grade ore is an established long-term trend (Mason et al., 2010). For example, in Australia the average $\mathrm{Cu}$ grade was c. $10 \%$ in 1885 but it fell to $1 \%$ by 2005 , whereas in Canada the average Ni grade was c. $5 \%$ in 1885 and fell to $1.5 \%$ by 2005 (Giurco, 2010). This trend was made possible by the high demand for metals in 2005 to 2008, and the resulting sharp increase in their prices resulted in the extraction of still lower grade ores with high tailings to concentrate ratios (e.g., Blas and Bream, 2008). Furthermore, there is historical evidence that periods of increasing metal prices correlate with a high rate of tailings dam failure occurring some 24-36 months after the increase peaks (Davies and Martin, 2009). This correlation results from a frantic boom-time activity where safety and legislative restrictions were not perhaps in the forefront of operators' minds. Long-term improvements in processing efficiency make the working of low-grade ores more economic, thereby further increasing the global tailings burden (e.g., Mehrabani et al., 2010). The mining of precious metal ores often results in still higher tailings ratios. For example, the average grade of gold between 1830 and 1900 was around $20 \mathrm{~g} \mathrm{t}^{-1} \mathrm{Au}$, but this grade has been falling steadily since this time (Müller and Frimmel, 2010). If this trend is extrapolated into the future, the grade could 
fall to $2 \mathrm{~g} \mathrm{t}^{-1}$ by the year 2050 and to as little as $0.7 \mathrm{~g} \mathrm{t}^{-1}$ by the year 2100 (Müller and Frimmel, 2010). Thus the task of storing mine tailings safely and efficiently is a substantial one and, crucially, almost certain to be on a significantly greater scale in the future.

\subsection{Physical properties of tailings}

Tailings particles commonly are angular to very angular, and this morphology imposes a high friction angle on dry tailings (Mulligan, 1996; Sarsby, 2000; Bjelkevik, 2005). Tailings grain size is highly variable and difficult to generalize, as it is delineated by specific process requirements. Despite this, Sarsby (2000) defined hard rock tailings particle sizes as largely gravel-free $(<2 \mathrm{~mm})$ and clay-free $(<3.9 \mu \mathrm{m})$, with sand $(625 \mu \mathrm{m}-2 \mathrm{~mm})$ being more common than silt $(3.9 \mu \mathrm{m}-625$ $\mu \mathrm{m})$. Density varies according to the parent rock type. A generalized range for tailings bulk density is given as $1.8-1.9 \mathrm{t} \mathrm{m}^{-3}$ with a specific gravity of 2.6 -2.8 (Sarsby, 2000; Bjelkevik, 2005). Within tailings piles there is an increase in bulk density with depth as the result of compaction, dewatering and diagenesis. Sarsby (2000), for example, gives a gradient of $0.09-0.17 \mathrm{t} \mathrm{m}^{-3}$ per $30 \mathrm{~m}$ depth change. The froth flotation process utilizes flocculants to render targeted metal cations hydrophobic in order that they may be separated from the bulk material. This process has a requirement for fine silt-sized particles (Younger and Wolkersdorfer, 2004). The froth flotation method has an ideal grain size requirement of $300-50 \mu \mathrm{m}$ (Smolders et al., 2003). The gravitational settling method, which relies on the density differential between the heavier sulfide and lighter silicate fractions, utilizes a significantly larger grain size of around $1 \mathrm{~mm}$. Thus, the tailings grains from the froth flotation method have a comparatively smaller radius. Hence, according to Stokes Law, they have a relatively low settling velocity (Atkins, 1995). In a fluvial environment, these comparatively smaller sized grains will be carried further downstream, potentially threatening a greater area of floodplain, or perhaps alternatively allowing for greater sediment/aqueous dilution. Additionally, as a function of their small size, these grains have a relatively large surface area to volume ratio. This 
renders them kinetically prone to oxidation and the likely ensuing release of sorbed or structurally incorporated contaminant elements (e.g., sulphide oxidation and release of $\mathrm{Cu}$ and $\mathrm{Mn}$, Kossoff et al., 2012a).

\subsection{Chemistry of tailings}

The chemical composition of tailings depends on the mineralogy of the ore body, the nature of the processing fluids used to extract the economic metals, the efficiency of the extraction process and the degree of weathering during storage in the dammed impoundment. Major element compositions of tailings are not always given in the literature as the foci of most studies are the potentially toxic trace metal and metalloid elements. Silica and Fe presence, however, are almost universal and, together with oxygen, are usually the most abundant elements, with $\mathrm{Al}, \mathrm{Ca}, \mathrm{K}, \mathrm{Mg}, \mathrm{Mn}, \mathrm{Na}, \mathrm{P}, \mathrm{Ti}$ and $\mathrm{S}$ also major components (Table 1). The degree of metal and metalloid process extraction depends upon the economic interplay between the extent of plant investment and efficiency and the price of the particular targeted metal or metalloid (Dixon-Hardy and Engels, 2007). Therefore, there are always metals and metalloids other than Fe present in tailings, because no extraction process is ever $100 \%$ efficient. Although there is no universally accepted protocol for directing which trace elements are measured in tailings studies, $\mathrm{As}, \mathrm{Cu}, \mathrm{Pb}$ and $\mathrm{Zn}$ are normally quantified, and generally have high concentrations (e.g., David, 2003; Hudson-Edwards et al., 2003; Rabinowitz, 2005; Meck et al., 2006). If $\mathrm{Zn}$ concentrations are high, $\mathrm{Cd}$ is also measured due to their chemical similarities (e.g., Hellström et al., 2007; Kossoff et al., 2011). Mercury, Sb and Tl may also be monitored (Zhang et al., 1998; Filella et al., 2002; Miller et al., 2004; Lottermoser and Ashley, 2005; Hellström et al., 2007), especially where there is pre-existing evidence of locally high concentrations (e.g., Tl in Lanmuchang, China; Xiao et al., 2004). Although not as common as in sulfidic tailings, pyrite is often a significant phase in coal mine spoil, whereas chalcopyrite, sphalerite, galena and pyrrhotite may also be present in detectable quantities (Gupta 1999; Dang et 
al., 2002). Hence, the chalcophilic elements (Ag, As, Bi, Cd, Cu, Ga, Ge, Hg, In, Pb, Po, S, Sb, Se, $\mathrm{Sn}, \mathrm{Te}, \mathrm{Tl}$ and $\mathrm{Zn}$ ) are often commonly elevated in coal. For example, in the Appalachian coal deposits the average As concentrations in pyrite range from 944 to $2700 \mathrm{mg} \mathrm{kg}^{-1}$ in samples sourced from Kentucky and Alabama, respectively (Diehl et al., 2012). Some non pyrite-bearing coals in Guizhou Province contain up to 3.5\% wt. \% As (Li et al., 2012). In practice, however, adverse drainage from coal-mine tips is not as critical an environmental problem as from coal combustion and its products (e.g., Shraim et al., 2003; Ruhl et al., 2009). This is likely a function of the capacity of organic compounds and iron oxyhydroxides contained within the coal to complex contaminants and thus mitigate toxicity (Dang et al., 2002).

\subsection{Mineralogy of tailings}

Tailings minerals may be divided into three broad categories: the gangue fraction, the residual uneconomic sulfide-oxide fraction and the secondary mineral fraction (Fig. 1b). In sulfide tailings remaining from base and precious metal extraction, the gangue fraction is dominated by quartz $\left(\mathrm{SiO}_{2}\right)$, and also can comprise $\mathrm{K}$-feldspar $\left(\mathrm{KAlSi}_{3} \mathrm{O}_{8}\right)$, Na-feldspar $\left(\mathrm{NaAlSi}_{3} \mathrm{O}_{8}\right)$ and $\mathrm{Ca}$-feldspar $\left(\mathrm{CaAl}_{2} \mathrm{Si}_{2} \mathrm{O}_{8}\right)$, sericite $\left(\left(\mathrm{KAl}_{2}\left(\mathrm{AlSi}_{3} \mathrm{O}_{10}\right)(\mathrm{F}, \mathrm{OH})_{2}\right)\right.$, chlorite $\left((\mathrm{Mg}, \mathrm{Fe})_{3}(\mathrm{Si}, \mathrm{Al})_{4} \mathrm{O}_{10}(\mathrm{OH})_{2}(\mathrm{OH})_{6}\right)$, calcite $\left(\mathrm{CaCO}_{3}\right)$ and dolomite $\left(\mathrm{Ca}, \mathrm{Mg}\left(\mathrm{CO}_{3}\right)_{2}\right)$ (Rutley and Read, 1970; Lottermoser, 2007). Within the sulfide-oxide fraction pyrite $\left(\mathrm{FeS}_{2}\right)$ is almost ubiquitous, whereas pyrrhotite $\left(\mathrm{Fe}_{1-\mathrm{n}} \mathrm{S}\right.$ where $\mathrm{n}$ ranges from 0-0.2), arsenopyrite $(\mathrm{FeAsS})$, marcasite $\left(\mathrm{FeS}_{2}\right)$, magnetite $\left(\mathrm{Fe}_{3} \mathrm{O}_{4}\right)$, sphalerite $(\mathrm{ZnS})$, chalcopyrite $\left(\mathrm{CuFeS}_{2}\right)$ and galena $(\mathrm{PbS})$ are also common (Keith and Vaughan, 2000). Depending on the mineralogy of the original orebody, other sulfide and oxide minerals can be found in this fraction. Examples include pentlandite $\left((\mathrm{Fe}, \mathrm{Ni}){ }_{9} \mathrm{~S}_{8}\right)$, stibnite $\left(\mathrm{SbS}_{2}\right)$, cassiterite $\left(\mathrm{SnO}_{2}\right)$ and wolframite (Fe,Mn)WO $\mathrm{W}_{4}$ (Rutley and Read, 1970; Robb, 2004; Kossoff et al., 2011, 2012a, b).

Fresh tailings grains weather in the field when exposed to oxic conditions, and secondary oxidized minerals form. Depending on the interaction between source mineralogy and local 
conditions, such as $\mathrm{pH}$, climate and redox state, particular secondary minerals may form. Some common examples include goethite $(\alpha-\mathrm{FeOOH})$, gypsum $\left(\mathrm{CaSO}_{4} \cdot 2 \mathrm{H}_{2} \mathrm{O}\right)$, anglesite $\left(\mathrm{PbSO}_{4}\right)$, melanterite $\left(\mathrm{FeSO}_{4} \cdot 7 \mathrm{H}_{2} \mathrm{O}\right)$, jarosite $\left(\mathrm{KFe}_{3}\left(\mathrm{SO}_{4}\right)_{2}(\mathrm{OH})_{6}\right)($ Fig. $1 \mathrm{~b})$, scorodite $\left(\mathrm{FeAsO}_{4} \cdot 2 \mathrm{H}_{2} \mathrm{O}\right)$ and kaolinite $\left(\left(\mathrm{Al}_{2} \mathrm{Si}_{2} \mathrm{O}_{5}(\mathrm{OH})_{4}\right)\right.$. The secondary mineral assemblage often hosts the major contaminant metals and metalloids by both structural incorporation and surface sorption. For example, As and $\mathrm{Pb}$ are structural components of scorodite and plumbojarosite $\left(\mathrm{Pb}_{0.5} \mathrm{Fe}_{3}\left(\mathrm{SO}_{4}\right)_{2}(\mathrm{OH})_{6}\right)$, respectively. Hence, those particular contaminant sinks function for as long as the secondary minerals themselves remain stable, and beyond, depending on the rate of dissolution. The surface of any mineral is, by definition, a large-scale crystallographic defect where mineral ions are available for complexation (or sorption) by solute ions. In this respect the negatively charged oxygen atoms in secondary minerals such as sulfates, carbonates, phosphates and arsenates may be significant sorption sites, with the negatively charged hydroxyl and oxygen ions found on the surface of primary and secondary oxide and clay minerals of particular significance.

\section{Storage of tailings in dammed impoundments}

Approaches to the handling and storage of tailings include riverine disposal, submarine disposal, wetland retention, backfilling, dry stacking and storage behind dammed impoundments (Lottermoser, 2007). The main method currently employed (especially by large companies in the Developed World) is the latter, with the structures produced often termed 'tailings ponds' (Fig. 1c) or 'tailings dams'. The tailings are normally stored under water to prevent the formation of surface dusts and of acid mine drainage (by forestalling oxidation), especially when large amounts of acidgenerating pyrite and pyrrhotite are present. The maintenance of an adequate water level may be problematic, particularly in arid and semi-arid areas. In these areas the establishment of a vadose zone within the impoundment may well facilitate the ingress of contaminant metal(loids) into the 
local groundwater (Smuda et al., 2014). There are at least 3500 tailings dams worldwide (Martin and Davies, 2000) and these range in area from a few ha to some thousands of ha (Davies et al., 2000; Lottermoser, 2007). For example, the Inco Ltd. Central Tailings Disposal Area (Sudbury, Ontario, Canada) covers an area of $25 \mathrm{~km}^{2}$ with a $50 \mathrm{~m}$ depth of tailings, and has an ultimate envisaged capacity of more than $725 \mathrm{Mt}$ (Puro et al., 1995). The New Cornelia tailings Cu tailings dam in Arizona is said to be the largest dam structure (by volume) in the USA, with a capacity of 29 $\mathrm{Mm}^{3}$ and a diameter of $2.5 \mathrm{~km}$ (Engels and Dixon-Hardy, 2012). Even the relatively small tailings impoundment at the Lisheen $\mathrm{Pb}-\mathrm{Zn}$ mine in Tipperary, Ireland, was constructed with a planned capacity of over $5 \mathrm{Mm}^{3}$ (Dillon et al., 2004).

Tailings dams are commonly constructed from readily available local materials, rather than the concrete used, for example, in water-retention dams. Although the initial dyke is commonly made of locally-derived soil (Álvarez-Valero et al., 2009; Chakraborty and Choudhury, 2009), waste rock and the tailings themselves are often used in construction (Younger and Wolkersdorfer, 2004; Bussière et al., 2007; Dixon-Hardy and Engels, 2007). Rather than initially installing a finalized full capacity structure, intermediate retaining embankments are normally constructed and then raised as storage demand increases (Lottermoser, 2007). After the initial structure has been constructed the embankments can either be raised upstream, vertically (centre-line), or downstream (Martin and McRoberts, 1999). Upstream raising is achieved by the placing of the new material within the existing impoundment, centre-line raising is accomplished by placing new material directly on top of the existing embankment, whereas downstream raising describes the raising of the embankment by placing the new material outside the impoundment (Fig. 2). Of these three methods of construction upstream raising is the cheapest, as a smaller amount of building material is required (Soares et al., 2000).

Tailings are normally pumped from the mill to the impoundment as slurry. At the impoundment site common dispersal methods include cycloning or dispersal through spiggoting to 
achieve size differentiation of the material. Size-differentiated dispersal not only helps to preserve the integrity of the dam by placing the coarser more porous material in the structure itself (see below), but also results in the finer fraction forming an impermeable barrier, which in turn reduces piping or seepage across the dam structure. This practice, however, may lead to the possibility of a sub-horizontal water table forming, with the area closest to the discharge point being more exposed to atmospheric $\mathrm{O}_{2}$ and, possibly, alternating wet and dry cycling. Consequently, it is good practice to place a number of tailings discharge points around the impoundment and use them sequentially (Dixon-Hardy and Engels, 2007).

Piping through a tailings dam is an erosional process that results in an undermining patent liquid channel or pipe being established through the structure. Therefore, piping might be described as a process of large-scale seepage. A common cause of piping is the deposition of thin layers of fine tailings between thicker layers of coarse tailings as the dam is raised. This is a function of inadequately monitored upstream raising and / or inadequately constrained particle size dispersion (Van Niekerk and Viljoen, 2005).

In order to preserve structural integrity of successive raises of dams, they are ideally underlain by a competent sand-sized layer rather than a loose, potentially incompetent clay-sized. To that end the raising rate of the dam structure is normally restrained in order to ensure that each new layer is well compacted. It is also good practice to ensure that the foundation is well drained, thus serving to maintain a low phreatic surface (Fig. 3). To that end it is appropriate to allow for good drainage of the dam by providing for a wide tailings 'beach' (defined as the sub-aerial tailings disposal point), which differentiates the tailings material by size, ensuring that the sand size larger (more permeable) particles form the dam structure, whereas finer (less permeable) clay sized particles are more distally dispersed. The integrity of the liner, which is usually made of clay, is a key factor in the long-term performance of a tailings dam (Van Zyl et al., 1988). If the tailings are 
predicted to generate acid mine drainage (AMD), the liners are often tested with modeled or actual AMD fluid before final installation (Shackelford et al., 2010).

\section{Causes of tailings dam failures}

Several reviews have compiled information on tailings dam failures (e.g., USCOLD, 1994; Davies et al., 2000; Engels and Dixon-Hardy, 2012; Rico et al., 2008a; WISE, 2012), and key examples of these are summarized in Table 2 and depicted in Fig. 4. Although the published data are unquestionably valuable, they are incomplete, as smaller incidents are very common (e.g., Villarroel et al., 2006) and are under-reported in both the scientific literature and popular media. It is also thought that many, if not the majority of failures are not reported due to fears of bad publicity and legal ramifications (Davies, 2002), particularly in China and Russia. The current rate of major tailings dam failure has been estimated as being of the order of two to five per annum (Davies, 2001). Given the total number of current tailings impoundments is c. 3,500, the rate of failure is one in 700 to one in 1,750 . This is a much higher rate than that of the major failure of water-retaining dam, which is approximately one in 10,000 (Davies, 2001).

The available data suggest that active rather than inactive impoundments are most likely to fail. Rico et al. (2008b), from an extensive analysis of European tailings dam failure data, concluded that $83 \%$ of failures occurred when the dam was active, $15 \%$ occurred in inactive and abandoned dams and only $2 \%$ occurred in inactive but maintained dams. For inactive impoundments, overtopping has been cited as the primary failure mode in nearly one-half of the incidents (Davies, 2002). It is likely that a significant contributory factor accounting for the comparative stability of inactive tailings impoundments lies in the ongoing oxidation and cementation of tailings in the unsaturated zone (Fig. 1b gives a micro-scale view of this process). Troncoso (1990), for example, estimated that cementation may increase the liquefaction resistance 
of the impoundment by as much as $250 \%$ over 30 years. Cementation, too, may have the additional benefit of sequestering potentially toxic elements, such as $\mathrm{Pb}$ and $\mathrm{As}$, in secondary phases, for example, in calcite, gypsum and jarosite-group minerals (Jia and Demopoulos, 2005; Smith et al., 2006).

The causes of failure in active dams are more diverse than those for inactive impoundments, but some general conclusions may be drawn. Rico et al. (2008b) categorized failures into eleven broad groups: foundation, slope instability, overtopping, mine subsidence, unusual rain, snow melt, piping or seepage, seismic liquefaction, structural, maintenance and unknown causes. There is some obvious overlap between several of these categories (e.g., snow melt and overtopping) and nearly all occurrences may have multiple causes (e.g., poor maintenance and structural failure). However, Rico et al., 2008b) report that $25 \%$ of worldwide and $35 \%$ of European failures are accounted for by extreme meteorological events, a failure rate which may well increase with anthropogenicallyrelated climate change.

Upstream raised dams (Fig. 2) are the most likely to fail (Davies, 2002; Rico et al., 2008a, b; Table 2). Such dams have been said to be 'unforgiving structures' (Martin and McRoberts, 1999), for which good design practice and stewardship are vitally important if integrity is to be maintained (Martin and Davies, 2000). One of the major potential hazards of upstream dam construction is failure through static liquefaction (Martin et al., 2002). This may be defined as the loss of solid properties in response to an applied stress causing the material to behave in a liquid-like manner; such behavior obviously being highly prejudicial to the stability of a tailings dam. The applied stress may result from mine blasting, or the motion of heavy equipment, but the chief danger, in seismically susceptible areas, is from earthquakes. Examples of seismically induced incidents include the failure of six Chilean dams during the 1965 earthquake (Dobry and Alvarez, 1967), two Chilean dams during the 1985 earthquake (Castro and Troncoso, 1989), dams at Hokaido, Japan after the 1968 earthquake (Prakash et al., 1998), Mochikoshi, Japan after the 1978 earthquake 
(Byrne and Seid-Karbasi, 2003), Nazca, Peru during the 1996 earthquake (Psarropoulos et al., 2005) and at Maule, Chile following the 2010 earthquake (Verdugo et al., 2012). Some authors conclude that upstream raising is not a suitable construction method in seismically susceptible areas (e.g., USEPA, 1994), whereas others do not go this far, but instead strongly emphasize the risks involved. The latter group stresses the particular importance of a robust design and good maintenance programme that have been specifically tailored for the particular site, taking into account potential failure mechanisms (e.g., Martin and McRoberts, 1999).

Another frequent cause of dam impoundment failure, particularly for active impoundments, is foundation failure. The permeability of the foundation is a vital constraint on the stability of the dam structure itself. Low permeability foundation material tends to raise pore pressure and thus render the overall structure vulnerable to shear stress (Hustrulid, 2000). On the other hand, too pervious a construction material can render the foundation structure vulnerable to piping failure (see above). Moreover, structurally weak material beneath the structure, such as buried pre-weathered slopes, alternating fine and thin layers etc., will render the foundation susceptible to shear stress. Such geotechnical factors are not often given due weight in determining the siting of embankment dams. A selection of other factors, such as local topography, mill-impoundment distance and catchment area size were often more given more weight in the past, principally for economic reasons (USEPA, 1994).

The integrity of tailings dams is dependent on both good design and maintenance. Most failures are preceded by warning signs, except for those triggered by earthquake or major storm events (Martin and Davies, 2000). Good maintenance programmes are, therefore, an essential requirement of effective tailings impoundment management, a vital component of which is a comprehensive surveillance programme (Martin and Davies, 2000). Structure settlement cracking and wet spots on the dam face are all good qualitative visual indications of potential problems. Piezometers, clinometers and pressure gauges may all be employed to good effect in a sensibly 
designed monitoring protocol (Vick, 1983; Vandeberg et al., 2011). The combination of these data with properly maintained operational logs (e.g., recording dates, locations and meteorological conditions at the time of disposal) allows for a reliable quantification of risk, thereby enabling effective proactive preventive responses.

\section{Environmental impacts of tailings dam failures}

\subsection{Immediate (hours to months) impacts}

The sheer magnitude and often toxic nature of the material held within tailings dams means that their failure, and the ensuing discharge into river systems, will invariably affect water and sediment quality, and aquatic and human life for potentially hundreds of km downstream (Edwards, 1996; Macklin et al. 1996; Anonymous, 2000; Hudson-Edwards et al., 2003; Macklin et al., 2003; Macklin et al., 2006; Fig. 4). Records indicate that thousands of people have died from tailings dam failures (WISE, 2012). For example, around 4,000 people were killed in the flood resulting from the March 1626 failure of the San Ildefonso (Potosí, Bolivia) dam. The collapse of two tailings impoundments at Stava in northern Italy and the ensuing flooding of the eponymous village in 1985 directly led to around 250 deaths by drowning or suffocation (Chandler and Tosatti, 1996; Davies, 2001). Seventeen fatalities were recorded following the Merriespruit (South Africa) dam failure of 1994 (Davies et al., 2000; Fourie et al., 2001), and ten people died directly following the Ajka, Hungary red mud spill on 4 October 2010 (Ruyters et al., 2011). In the immediate aftermath of a severe dam break the deaths reported are largely the results of drowning and suffocation. Over the medium- to long-term many more deaths may occur as a result of toxicity, but no direct links to tailings dam failures have been made. However, leakage of contaminants such as $\mathrm{As}$ and $\mathrm{Pb}$ into the wider environment, particularly where tailings dam spills compound already elevated floodplain concentrations, almost certainly results in increased rates of pathology and, by extension, mortality. This was seen, for example, following the Mid-Wales summer floods of 2012 (Foulds et al., 2014), 
when historically $\mathrm{Pb}$ contaminated flood sediments were inadvertently incorporated in silage resulting in poisoning and death of cattle.

The impact of tailings dam breaks on fish and terrestrial animal and plant life can be just as severe. On 25 April 1998 some $1.3 \times 10^{6} \mathrm{~m}^{3}$ of tailings were deposited over $26 \mathrm{~km}^{2}$ of the Guadiamar River Basin following the breach of Aznalcóllar dam at the Boliden Los Frailes Ag-Cu$\mathrm{Pb}-\mathrm{Zn}$ mine facility (López-Pamo et al., 1999; Hudson-Edwards et al., 2003). No immediate human fatalities were reported, but metal and As contamination were widespread in the largely agricultural Guadiamar basin and threatened the ecologically significant Doñana National Park (Grimalt et al., 1999). For instance, as a direct result of the spill, all of the fish and shellfish present in the polluted watercourses were killed. This was due to a combination of burial, impact, mud blocking the gills and the extreme change in water chemistry (the $\mathrm{pH}$ fell to around 3 and dissolved oxygen fell to c. 0.5-1 $\left.\mathrm{g} \mathrm{L}^{-1}\right)$. Thirty-seven tonnes of dead fish were collected in the month following the accident, whereas all of the dead crabs and shellfish disappeared into the contaminated mud (Grimalt et al., 1999).

On 30 January and 10 March 2000 two separate tailings dam bursts occurred at Baia Mare and Baia Borsa, Romania, close to the Ukrainian border (Macklin et al., 2003). The tailings from both spills were released into the River Tisa, a major Danube tributary. The first failure occurred at a newly constructed gold and silver reprocessing facility and, as a consequence, there was a significant spill of extractant cyanide as a tailings component. Lásló (2006) calculated that the January spill released up to 120 tonnes of cyanide and metallic elements into the catchment, whereas the March spill, although not as extensive, released significant amounts of $\mathrm{Pb}, \mathrm{Cu}$ and $\mathrm{Zn}$. The toxic effects of both spills resulted in contamination and fish deaths not only in Romania, but also in Hungary, Serbia and Bulgaria, thereby emphasizing the potential cross-border international consequences of severe tailings dam failure incidents (Hudson, 2001; Macklin et al., 2003). In the immediate aftermath of the spill 1,240 t of fish were reported killed (Lásló, 2006). In international 
and distance down-basin contexts, cyanide spills are particularly problematical because the cyanide readily forms an aqueous complex with metals such as $\mathrm{Cu}, \mathrm{Fe}, \mathrm{Ni}$ and $\mathrm{Zn}$ (Rees and Van Deventer, 1999). These metallic elements are thereby kept in solution over much greater distances than would be the case without the cyanide. This is likely one of the reasons that some authors recommend that cyanide waste be treated and removed 'in plant' before being deposited in impoundments (Hoskin, 2003).

Dam failures can inundate river systems with vast amounts of tailings. For instance, immediately after the March 1626 failure of the Bolivian San Ildefonso dam, enormous quantities of tailings and $\mathrm{Hg}$ amalgam were released into the Pilcomayo catchment (Rudolph 1936; Gioda et al., 2002). Gioda et al. (2002) recounted that 19 tonnes of $\mathrm{Hg}$ were released in a period of just two hours. It is highly likely that a significant proportion of the elevated $\mathrm{Hg}$ concentrations on present day floodplain is derived from this incident (Hudson-Edwards et al., 2001). Approximately $1.9 \mathrm{x}$ $10^{5} \mathrm{~m}^{3}$ of liquefied fluorite tailings were released from the two Stava (Italy) tailings dam failures. The resultant flood traveled at a speed of up to $60 \mathrm{~km} \mathrm{~h}^{-1}$ and a distance of $4 \mathrm{~km}$ downstream (Chandler and Tosatti, 1996; Davies, 2001). The Merriespruit (South Africa) dam failure occurred following a heavy rainstorm and released some $6.0 \times 10^{5} \mathrm{~m}^{3}$ of gold tailings and process material some $3 \mathrm{~km}$ downstream (Davies et al., 2000; Fourie et al., 2001). The Ajka, Hungary spill on 4 October 2010, released $7.0 \times 10^{5} \mathrm{~m}^{3}$ of $\mathrm{Al}$ tailings and bauxite processing effluent, with a $\mathrm{pH}$ of 13.5, into the Torna Creek and Marcal River. Finally, in the morning hours of July $16^{\text {th }}$, 1979 , an earthen dam at Church Rock Mill (New Mexico) failed, releasing 1,100 t of radioactive waste and 360 million 1 of process effluent into the north fork of the Puerco River. In the ensuing flood contaminants were transported $130 \mathrm{~km}$ downstream (Graf, 1990; Brugge et al., 2007). Production resumed two weeks after the accident, and the resulting effluent was placed in unlined pits, further threatening water quality (USEPA, 2010). Furthermore, the USEPA (2010) stress that at the Church Rock site 'currently, groundwater migration is not under control.' The acute release of radioactive 
waste from the Church Rock tailings impoundment occurred in the same year as that of the Three Mile Island partial core meltdown accident (Rogovin, 1979). It has been estimated that the radiation released was of a similar order of magnitude, with the Church Rock release being estimated at 46 $\mathrm{Ci}$, and the Three Mile Island release at $13 \mathrm{Ci}$ (Brugge et al., 2007).

Invariably associated with sulfide tailings oxidation is the potential for metal and metalloid mobilization and acidification. Hence, in the aftermath of a tailings dam flood the concentration of contaminant elements in floodplain standing and pore water maybe so high as to adversely affect vegetation and arable crops. For example, an area of 4,286 ha was contaminated by the Aznalcóllar breech, of which 2,557 ha were agricultural. From 13 May 1998 all agricultural products from the affected area were harvested for destruction, whereas on the 9-18 June the Andalusian authorities instigated a compulsory purchase program for all of the affected land (Grimalt et al., 1999). Table 3 provides some data on fluvial metal concentrations in the aftermath of a tailings dam break, together with some selected advisory maxima for irrigation and drinking water concentrations. The data show that after the Aznalcóllar dam break, for example, all of the regulatory maxima were exceeded apart for that for $\mathrm{Cu}$. The contaminant metals present are very much a function of the particular site. In the case of Ajka, for example, Al concentrations were very high as one might expect; however, the high concentrations of Mo provide a particularly salient example of contamination not sourced from the mine waste material itself. Molybdenum was not present in particularly high concentrations in the red mud (11-18 $\left.\mathrm{mg} \mathrm{kg}^{-1}\right)$. It was, however, found in elevated concentrations in the fly ash material used to construct the breached dam itself $\left(53 \mathrm{mg} \mathrm{kg}^{-1}\right)$. Therefore, in this case, the dam, rather than the tailings was the likely source of contamination (Mayes et al., 2011).

Aqueous dilution lowers contaminant concentrations downstream of a spill, particularly where the river receives waters from a clean tributary. Soon after the Porco (Bolivia) impoundment failure Macklin et al. (1996) reported very high levels of contamination in the Pilcomayo and its tributary the Pilaya. Sampling on 12 and 13 November 1996 showed that river waters collected next 
to the dam breach had $>2,500 \mathrm{mg} \mathrm{L}^{-1} \mathrm{~Pb}$, and that this only fell gradually over $50 \mathrm{~km}$ to concentrations of $\sim 500 \mathrm{mg} \mathrm{L}^{-1}$. These latter concentrations, however, were maintained at least 500 $\mathrm{km}$ downstream. Immediately following the spill the fish kill was also extensive, reaching as far as $500 \mathrm{~km}$ downstream of the breach (Macklin et al., 2006). By 1997, downstream river Pb concentrations had fallen considerably, largely to below regulatory limits as a function of dilution (Smolders and Smolders, 1998).

Rivers, particularly in mountainous and dryland environments, may carry very large sediment loads. The Pilcomayo, for example, has a suspended sediment load of $10.6 \mathrm{~g} \mathrm{~L}^{-1}$ (Smolders et al., 2002), and this quantity has been calculated as being sufficient to annually cover an area of 5000 ha with a layer one m thick (Smolders et al., 2002). Thus, as well as aqueous dilution by clean water, dilution by the river's sediment load will serve to considerably mitigate the medium- long-term adverse effects of tailings dam spills (Hudson Edwards et al., 2001, 2003), as it does in many other catchments worldwide affected by historical metal mining pollution (Lewin and Macklin, 1987). Calculations show that $\sim 50$ t of Pilcomayo soil will permanently buffer 1 tonne of well mixed tailings, which, given the vast sediment load, at least partially explains the mitigation of AMD that was observed in the downstream Pilcomayo (Hudson Edwards et al., 2001; Kossoff et al., 2012a). If the soil and tailings are not well mixed as, for example, after a tailings dam breech, the potential for AMD generation is correspondingly higher. Furthermore, undisturbed dam spillderived tailings deposited on the surfaces of floodplains are highly susceptible to atmospheric oxidation, thereby compounding their AMD generating capacity (see below).

Overall, dilution notwithstanding, the acute effects of a spill are commonly severe. In the medium- to longer-term, however, influences of a spill on a river basin's biota are difficult to disentangle from those of on-going lower grade contamination (e.g., Hudson-Edwards et al., 2001; Macklin et al., 2003). Nevertheless it is clear that the adverse dam spill effects will be cumulative with those arising from chronic contamination. 


\subsection{Medium- to longer-term (years to centuries) impacts}

\subsubsection{Contamination of water}

Tailings dam spills can contaminate natural waters in the short-term, but in the medium- to longerterm (years to centuries) contaminant concentrations are likely to fall because of the effects of sediment and aqueous dilution and uptake by solid phases in the river bed and floodplain. For example, in the Guadiamar catchment (which was affected by the 1998 Aznalcóllar tailings dam spill) concentrations of metal contaminants in surface waters decreased after the spill and cleanup, and now generally lie within acceptable European Union limits (Turner, 2003). Isolated hot spots of contamination, however, remained ten years after the accident, particularly in areas proximal to the dam breech (Olías et al., 2012). Specific areas of concern remain however, as a consequence of the on-going physical recovery and adjustment of the river channel and floodplain to post-spill conditions (Macklin et al., 2006; Turner et al., 2008). The extensive excavation of channel bed, bank and floodplain sediment, and removal of riparian vegetation, undertaken after the spill did leave a highly unstable river channel. This resulted in accelerated bank and bed erosion in the upper parts of the Rio Guadiamar and high rates of sedimentation in the lower reaches of the Guadiamar catchment. It also inadvertently further increased contamination of the catchment by releasing sediment contaminated by historical (pre-spill) mining activities. Similar potential historical contaminant remobilization risks have been identified in other catchments affected by tailings dam spills, such as the Marcal basin following the Ajka spill (see below; Klebercz et al., 2012).

Amongst the generally monitored contaminants (particularly from sulfide tailings), As is present as an anion in solution (Cheng et al., 2009). Hence, in the aftermath of a spill, as fluvial conditions recover and $\mathrm{pH}$ returns from acidic values to circumneutral/moderately alkaline values, As may be competitively desorbed from phases such as Fe oxyhydroxides (Olías et al., 2004). Indeed, Hudson- Edwards et al. (2005) report an increase in As concentration with distance 
downstream in the Guadiamar in May 1999, which may be a consequence of desorption following a reduction of riverine acidity.

Although no cleanup operations were undertaken after the Porco (Bolivia) accident it is noteworthy that in the medium- to longer-term water quality showed no obvious lasting adverse effects from the spill itself. However, chronic contamination from ongoing unregulated discharge of tailings into the water-course, and drainage through old workings remains a matter of concern (Hudson-Edwards et al., 2001). The relatively complete recovery of the Bolivian Pilaya/Pilcomayo aqueous system compared to that of the Spanish Guadiamar is the result of its high sediment load, where contaminants are both diluted and stored within an aggrading floodplain and river bed (Macklin et al., 2006). These examples clearly demonstrate the very significant role that river dynamics have on the rehabilitation of mining-affected catchments.

\subsubsection{Contamination of soils and sediments}

In a global context alluvial floodplains are often fertile environments, supporting animal husbandry and crop production. Floodplain contamination by metal and metalloid elements is a frequent, almost ubiquitous, result of failure, be it chronic or acute, and, once mobilized, many of these elements are potentially toxic to the biosphere in general and humans in particular (e.g., Lewin and Macklin, 1987; Macklin, 1996; Hudson Edwards et al., 2003; Liu et al., 2005; Rico et al., 2008a). The possible medium- to longer-term adverse effects of a dam spill on the floodplain environment are illustrated by data from the $\mathrm{Pb}-\mathrm{Zn}$ mine in Chenzhou, China. Here, a tailings dam collapsed on 25 August 1985 following heavy rains, inundating the Dong River valley. Strips of farmland $400 \mathrm{~m}$ wide along both river banks were covered with a $15 \mathrm{~cm}$-thick layer of black sludge. Cleanup efforts focused only on selected areas, leaving some agricultural land unremediated (Liu et al., 2005). Some 17 years later, in August 2002, the unremediated soil showed element concentrations far in excess of the Chinese soil Maximum Allowable Concentration (MAC) standard. Table 4 lists some 
examples of floodplain soil and sediment metal concentrations, providing both spatial and temporal data on river catchment soil and sediment contamination following a dam spill. These data indicate that soil and sediment contaminant concentration fall as a function of distance from the spill (cf. Macklin et al., 2006). An illustrative example is the Mike Horse (Montana, USA) tailing impoundment, which failed on 19 June 1975, releasing approximately 90,000 tonnes of tailings to Beartrap Creek and Blackfoot River as a result (Stiller, 2000). A comprehensive survey, involving 20 cross-valley transects at $5 \mathrm{~km}$ intervals, revealed that metal concentrations declined downstream of Mike Horse. The rate of decline, however, varied as a function of the particular contaminant, with $\mathrm{As}, \mathrm{Cd}$ and $\mathrm{Pb}$ declining at a significantly faster rate than $\mathrm{Cu}, \mathrm{Mn}$ and $\mathrm{Zn}$, indicating the heightened mobility of the latter group of elements (Vandeberg et al., 2011).

It should not be assumed that mining-related contaminants are permanently stored in fixed fluvial sedimentary reservoirs. Particularly striking examples of the remobilisation of contaminant metals are provided by the UK Yorkshire River Swale related to widespread floods in 2000 and, more recently, by the River Clarach, Mid-Wales, following floods in the summer of 2012. Mining had not taken place in the Swale catchment for more than 100 years and yet $\mathrm{Pb}$ concentrations in 2000 flood sediments within trunk river channels downstream of mined tributaries reached concentrations of $10,000 \mathrm{mg} \mathrm{kg}^{-1}$ (Dennis et al., 2003). Furthermore, more than $80 \mathrm{~km}$ downstream of the mining district, $\mathrm{Pb}$ concentrations in overbank flood sediments remained above $1,000 \mathrm{mg} \mathrm{kg}^{-1}$ (Dennis et al., 2003) as a consequence of the remobilisation of metals from historically polluted floodplain sediments by bank erosion during the flood event. Dennis et al. (2009) have calculated that 155,000 tonnes of $\mathrm{Pb}$, or $28 \%$ of the estimated total production, is stored within fluvial sediments in the Swale catchment. Similarly, in the historically mined Clarach catchment, MidWales, floods in June 2012 resulted in large-scale remobilisation of mining-contaminated sediment with concentrations of $\mathrm{Pb}$ exceeding $30,000 \mathrm{mg} \mathrm{kg}^{-1}$ (Foulds et al., 2014). Most significantly, silage 
produced from flood affected fields was found to contain up to $1900 \mathrm{mg} \mathrm{kg}^{-1}$ of sediment-associated $\mathrm{Pb}$, which led to cattle poisoning and subsequent mortality.

In terms of particle size, contaminants are often preferentially partitioned into the finer soil and sediment fractions as a consequence of their comparatively high surface area to volume ratio and the resulting heightened capacity to sorb contaminants (Dennis et al., 2003; Hudson Edwards et al., 2008). In arid/semi-arid areas, windblown mobilization of the finer grain fraction from soil, following either a spill or the ongoing effects of chronic contamination, can be significant (Csavina et al., 2012). Although not directly related to a tailings dam spill, except perhaps in the short-term when contaminants will be partitioned into a non-reworked surface layer, wind was shown to be a significant transport mechanism for contamination around an old $\mathrm{Pb}-\mathrm{Zn}$ mine in the Alcudia Valley, Spain (Rodríguez et al., 2009). Similarly, in a study of tailings from abandoned Au mines in Nova Scotia (Canada), Corriveau et al. (2011) established the presence of As in the easily wind-mobilized fine dust fraction $(<8 \mu \mathrm{m})$ at concentrations ranging from 65 to $1,040 \mathrm{ng} \mathrm{m}^{-3}$. One of the sample sites had a total As particulate concentration of 11,260 $\mathrm{ng} \mathrm{m}^{-3}$, well in excess of the 24 hour Province of Ontario's Ambient Air Quality Guideline for As of 3,000 ng m ${ }^{-3}$ (Corriveau et al., 2011). Furthermore, these particular tailings piles have been used for off road racing, which both prejudiced the health of the users. Elevated concentrations of contaminants (particularly As and to a lesser extent, $\mathrm{Pb}$ and $\mathrm{Zn}$ ) in the finer tailings fractions has also been reported from San Luis Potosí, Mexico (Castro-Larragoitia et al., 1997). Further examples of the importance of wind as a contaminant vector from surficial tailings have been reported from Broken Hill, Australia (Gulson et al.,1994), Kombat, Namibia (Mileusnić et al., 2014) and Potosí, Bolivia (Strosnider et al., 2008; Fig. 5).

The data presented thus far largely describe floodplain contamination by spills from sulfide tailings repositories. These, however, do not represent the only tailings-derived contamination of river systems. Moderate concentrations of metals and metalloids were present in the red mud sludge 
released during the Ajka (Hungary) red mud spill (Mayes et al., 2011), and these were delivered to the wider fluvial system following the spill. The Fe and Al oxides in the red mud are strong sorbents of metals, most of which form cations in solution when solubilized (Hasim et al., 2011; Hizal et al., 2013). However, metals and metalloids that form oxyanions in solution, such as As, Cr, Mo, and $\mathrm{V}$, are of more concern because of the net negative charge on the oxides brought about by the high pH of the red mud (Renforth et al., 2012). A survey conducted in the Ajka spill-affected area in December 2010 by Mayes et al. (2011) showed that concentrations of aqueous and sorbed metals and metalloids were not as high as had been initially feared. These comparatively low contaminant concentrations were attributed to both the success of the counter-measures employed in the immediate aftermath of the spill and the very fine grain size of the tailings particles, allowing for efficient dispersion and dilution. Nevertheless, significant residual concentrations of contaminants were present in the floodplain soils, and hotspots of floodplain contamination occurred where river sinuosity increased, and river gradients declined enabling finer particles to be deposited. One of the main elements of concern is the aluminium, which is highly mobile and probably phytotoxic, especially under alkaline conditions (Ma et al., 2003). Aluminium exhibited elevated concentrations in floodplain soils $\left(54,785\right.$ to $\left.75,160 \mathrm{mg} \mathrm{kg}^{-1}\right)$ relative to background concentrations (22,829 to 27,292 $\left.\mathrm{mg} \mathrm{kg}^{-1}\right)$ (Mayes et al., 2011).

To further illustrate the variety and potentially large scale of contamination following tailings dam failure, a massive release of coal combustion products occurred as a result of the collapse of a containing dam at Tennessee Valley Authority's (TVA) Kingston dam (near Harriman, Tennessee, USA) on 28 December 2008. The scale of the spill (at 4.1 million $\mathrm{m}^{3}$ ) makes it one of the largest, if not the largest, tailings spill on record, indicating the enormous volume of coal waste material stored (c.f., McLean and Johnes, 2000). The coal ash spilled into the River Emory, part of the Tennessee's catchment. The ash contained high levels of As $\left(75 \mathrm{mg} \mathrm{kg}^{-1}\right)$ and $\mathrm{Hg}\left(0.15 \mathrm{mg} \mathrm{kg}^{-}\right.$ ${ }^{1}$ ), as well as significant levels of radioactivity $\left({ }^{226} \mathrm{Ra}+{ }^{228} \mathrm{Ra}\right)$ (Ruhl et al., 2009). Additionally, the 
fine particle size of the ash rendered the material prone to aerial dispersion after its release, particularly from the floodplain's surface. Furthermore, a specific concern with coal fly ash is that small, and therefore directly inhalable, particles with a diameter of less than $10 \mu \mathrm{m}$ are relatively common.

In summary, to adequately assess medium- to long-term hazards posed by floodplain contamination resulting from mine tailings dam failures, a catchment's mining history, historical river channel and floodplain dynamics, current floodplain contaminant hotspots and their susceptibility to remobilisation must all be evaluated. In order to address these issues, and to mitigate possible future adverse effects, policies need to be developed that monitor, manage and remediate the fluvial environment in susceptible catchments (cf. Macklin et al., 2006; HudsonEdwards et al., 2008).

\section{Remediation of tailings dam failures}

Several options exist for remediation of tailings dam failures. Barriers can be constructed to contain the spilled material and prevent it from spreading further. The flood of tailings and acidic water arising from the 1998 Aznalcóllar-Los Frailes spill was impeded by walls at Entremeros that were constructed to protect the Doñana National Park, the largest reserve for birds in Europe and a UNESCO Reserve of the Biosphere (Grimalt et al., 1999).

Chemicals can be added to affected soils to reduce the mobility of the contaminants or neutralize the acidic or alkaline fluids. In the immediate aftermath of the 2010 Ajkai, Hungary spill the red mud was treated with gypsum, principally to lower the $\mathrm{pH}$ in an exchange reaction with bicarbonate, but also to sorb or co-precipitate contaminants, particularly As, $\mathrm{Cr}$ and $\mathrm{Mn}$ (Renforth et al., 2012). It appears as though this was an effective measure in lowering $\mathrm{pH}$ and thus ameliorating the more severe effects of the spill through the associated precipitation of these potential 
contaminants. The $\mathrm{Ca}$ from gypsum also improved soil structure by displacing $\mathrm{Na}$ from exchange complexes in clay minerals (Ruyters et al., 2011; Renforth et al., 2012). The alkaline conditions following red mud contamination increased the mobility of phosphate, consequently the application of fertilizer was recommended to the affected soils (Ruyters et al., 2011). By analyzing the data from field experiments, Madejón et al. (2010) also advocated repeated applications of organic amendments to promote long-term sustainability of the chemical stabilization of inorganic contaminants in soils affected by the Aznalcóllar-Los Frailes tailings dam spill. These organic amendments significantly increased $\mathrm{pH}$ and total organic carbon contents of the amended soils, and thereby reduced the inorganic contaminant extractability.

The most common remedial measure taken for tailings dam spills, however, is the removal of the spilled tailings from the affected areas to a storage area. Following the Aznalcóllar-Los Frailes spill, emergency removal of the tailings from the Ríos Agrio and Guadiamar began on May 3, 1998, continuing to December of that year, during which 4.7 million $\mathrm{m}^{3}$ of contaminated soil and vegetation was removed to the Los Frailes open pit (Grimalt et al., 1999; Hudson-Edwards et al., 2003). A second phase of cleanup took place during the summer of 1999 which removed a further 1 million $\mathrm{m}^{3}$ of material to the pit (Eriksson and Adamek, 2000; Turner et al., 2002). These actions, and the walls that were constructed at Entremuros, considerably reduced the medium- and longterm impacts on wildlife in the catchment (Hudson-Edwards et al., 2003). In Hunan, southern China, selected portions of the floodplain were cleaned up immediately after the collapse of the Chenzhou tailings dam, which held wastes from a $\mathrm{Pb}-\mathrm{Zn}$ mine (see above). Liu et al. (2005) determined $\mathrm{As}, \mathrm{Cd}, \mathrm{Cu}, \mathrm{Pb}$ and $\mathrm{Zn}$ contents in cereals, pulses and vegetables collected 17 years after the cleanup. Contaminant concentrations were indeed significantly lower in crops grown on the remediated soil, but even in these soils the Chinese MAC values were exceeded by the mean concentrations of As, $\mathrm{Zn}, \mathrm{Cd}$ and $\mathrm{Pb}$ (Liu et al., 2005; Table 4). Moreover, to a significant extent, the adverse effects of metal contamination were a function of crop variety. For example, the Cd 
concentration in rice grown on the unremediated land was $6.99 \mathrm{mg} \mathrm{kg}^{-1}$ (the Chinese critical maximum level is $0.4 \mathrm{mg} \mathrm{kg}^{-1}$ ), whereas the Cd concentrations in seeds and fruits were much lower and generally within recommended guidelines.

The importance of removing of tailings from affected soils following dam spills was reinforced by column weathering experiments carried out by Domènech et al. (2002a, b) and by Kossoff et al. (2011, 2012a, b). Domènech et al. (2002a, b) used tailings from the Aznalcóllar spill, and floodplain soil from the affected Guadiamar catchment, and conducted experiments to determine the mechanisms and kinetics of tailings oxidation by means of laboratory flow-through experiments at different $\mathrm{pH}$ and oxygen pressures. The tailings were composed mainly of pyrite (76\%), together with quartz, gypsum, clays, and sulfides of zinc, copper, and lead. The $\mathrm{pH}$ of the pore waters fell to c. 2 after 260 days, causing most of the Cd, Co and $\mathrm{Zn}$ to be leached from the columns. For the Kossoff et al. (2011, 2012a, b) experiments, sulfidic mine tailings sourced from the Bolivian polymetallic Cerro Rico de Potosí vein ores, and floodplain soil from an uncontaminated tributary of the Río Pilcomayo, were used. The columns were subjected to 20 cycles (over three calendar years) of alternating wetting and drying with simulated Bolivian rainwater to mimic wet and dry seasons, respectively. One column had a tailings layer placed on top of soil and tailings to model the effects of a dam failure on a contaminated floodplain. By the end of the experiment, the $\mathrm{pH}$ of the pore waters in this column had fallen from c. 7 to c. 2.5 due to oxidation of arsenopyrite, Fe-bearing sphalerite and especially, pyrite. In addition, significant amounts of the major and trace elements had been leached from the columns over the three calendar years (e.g., 3\% Al, 30\% As, c. 80\% Ca, 90\% Cd, 50\% Cu, 70\% Mn, 40\% S, 60\% Zn). These losses were attributed to the dissolution of minerals such as arsenopyrite, biotite, calcite, chalcopyrite, Mn oxides, pyrite, sphalerite and wurtzite. Proportionately more material was lost from this column than from another column which contained only mixed soil and tailings without the tailings cap, and this was attributed to the greater supply of $\mathrm{O}_{2}(\mathrm{~g})$ in the former, as the top layer of tailings was in 
constant contact with the atmosphere. Oxygen fugacity is one of the most important factors in the development of acid mine drainage (Blowes et al., 2003; Romano et al., 2003) and this process is catalysed by the presence of water, particularly when the water contains low concentrations of dissolved ions such as $\mathrm{Na}^{+}$and $\mathrm{Cl}^{-}$. Kossoff et al. (2012a) concluded that a comparatively thin layer of tailings from a dam breach lying atop a floodplain and exposed to the atmosphere, rainfall and periodic river flood inundations promotes maximum oxidation.

Local remedial measures, particularly those undertaken within areas of historical metal mining, can often be ineffective or even deleterious because river erosion and sedimentation processes operate at spatial and temporal scales beyond those typically used in point-source remediation (Macklin, 1996; Macklin et al., 2006). The inadvertent destabilization of the Guadiamar River, southwest Spain, by dredging of its channel to remove tailings and removal of contaminated floodplain soils and vegetation, is a cautionary tale in this respect (Turner et al., 2008). Furthermore, it is very difficult to predict precisely how river systems will recover after a large-scale tailings spill, with or without remediation. Modeling could provide a way forward and landscape evolution models, such as those developed by Coulthard and Macklin (2003), have been used to predict present and future levels and patterns of contamination. Coulthard and Macklin's (2003) study also revealed the exceptional longevity of contamination with greater than $70 \%$ of the deposited contaminants remaining in the historically mined Swale catchment, northern England, for more than 200 years after mine closure. Based on realistic simulations of a hybrid landscape evolution model combined with stochastic rainfall generation, Gamarra et al. (2013) have more recently demonstrated that similar remediation strategies may result in differing effects depending on catchment topography and hydrological regimes. Based on these results, they propose a conceptual model of catchment-scale remediation effectiveness based on three factors: (i) the degree of contaminant source coupling with the drainage network; (ii) the ratio of contaminated to non-contaminated sediment delivery; and (iii) the frequency of sediment transport events. This 
approach could be readily adopted for forecasting the likely speed and trajectory of catchment recovery following major tailings dam spills.

\section{Economic impacts of tailings dam failures}

Readily available and comprehensive data on the economic impacts of tailings dam failures are limited and incomplete, with compilations usually focusing on impacts on the environment, infrastructure and people (e.g., WISE, 2014). Here we primarily consider two important economic consequences of failures, which are business interruption (down time of mining and processing operations) and environmental damage and cleanup. Although not considered here, there are also the socio-economic and political issues associated with transboundary migration of effluent in rivers, as exemplified by the Baia Mare and Baia Borsa incidents in Romania, which affected Hungary and the former Yugoslavia (Lucas, 2001).

For mining and processing operations tailings typically represent the most significant environmental liability, which obligates a polluting party to pay for any and all damage it causes to the environment. The environmental liability that mining companies and their insurers may be exposed to is highlighted by the 1998 Aznalcóllar-Los Frailes spill and an excellent summary is provided by WISE (2013) using Spanish media reports. The spill occurred on 25 April 1998 and in August 2002 it was estimated that the Andalusian Government and the Spanish Environmental Ministry had spent 276 million Euros on the cleanup. To date they have received no compensation from Boliden and are still trying to obtain at least 134 million Euros from this mining company. In the meantime, Boliden has tried to claim damages of the order of 115 million Euros from the constructors (and their insurers) of the failed dam and an additional 134 million Euros to cover environmental damages. Since December 2011 the Spanish Supreme Court has declared that the construction companies are not guilty of wrongdoing and that Boliden is responsible for the spill, 
although it is yet to pay anything. For comparison, the Baia Mare cleanup cost around 190 million Euros and compensation was paid to the inhabitants of Baia Mare, but nobody else (Banerjee, 2014).

Evidently owners, operators and constructors of tailings dams may be exposed to huge environmental liability and associated economic losses and, therefore, risk may be transferred via insurance (Willis, 2012). In addition, tailings dam failures may lead to further losses arising from business and supply chain interruption, particularly when large third party material damage or casualties occur and authorities close down an operation (e.g., Mahrla, 2011). The impact of business interruption for Boliden's Los Frailes mine was huge. After the spill in April 1998 mining ceased for a year and subsequently mining and milling operations shut down completely in September 2001, with the dismissal of all 425 employees. Moreover, estimates are as high as 5,000 for other jobs lost in connection with agriculture, fishing, tourism and nature conservation in the region affected (Koziell and Omosa, 2003).

If mine owners and operators are to transfer risk associated with tailings dam failures, then the insurance community needs to ensure that its catastrophe models can adequately represent that risk. These models quantify hazards and the vulnerabilities of insured assets exposed to these hazards, ultimately giving a probability for an amount of loss. On a global scale the insurance community should be aware that the highest probabilities of tailings dam failures are associated with active impoundments (Rico et al., 2008b), with the main drivers of failure being extreme hydrometeorological events, foundation failure and seismic events. Consequently, storm, flood and earthquake catastrophe models should, where necessary, build in a module that adequately captures the risk from tailings dam failure. However, liquefaction is not modeled and yet it is a major cause of seismically driven failure, especially of upstream dams. Such is the vulnerability of these dams that it has been suggested that they should not be constructed in seismic zones (e.g., USEPA, 1994; ICOLD, 2001). 
The International Commission on Large Dams Tailings Dams Committee (ICOLD, 2001) concluded that to effectively reduce the cost of risk and failure of tailings dam and impoundment facilities, the owners and operators of these facilities must be committed to the adequate and enforced application of appropriate engineering technology to the design, construction and closure of the facilities over the entire period of their operating life. Particular attention must focus on active facilities as these are much more likely to fail than their inactive equivalents (e.g., Rico et al., 2008b).

\section{Conclusions}

The extent of mine waste production is currently of the same order of magnitude as that of fundamental Earth-shaping geological processes, some several thousand million tonnes per year. Moreover, as demand increases, and lower-grade deposits become increasingly worked, the global tailings burden is projected to be on an upwardly steep, if not exponential, path. The depletion of conventional reserves of oil and gas leading to the increased exploitation of tar oil sands deposits may also significantly increase that burden (e.g., Barton and Wallace, 1979; Nikiforuk, 2010; Kasperski and Mikula, 2011). Although it would be a mistake to unthinkingly adopt 'a one size fits all approach' the submerged retention of tailings in dammed impoundments, is most often the current storage method of choice, given both financial and environmental constraints. Hence, as tailings contain a multitude of varied contaminants, the integrity of these impoundments is a significant matter of global environmental concern. The main conclusion to be drawn from this review, therefore, is that tailings are best kept isolated from the floodplain environment in such watertight impoundments.

Our review has also emphasized the importance of an inter-disciplinary approach in addressing the problems of catchment-scale management in preventing or containing the effects of 
both an acute dam spill and chronic contamination. Further collaborative research in the fields of engineering (e.g., the influence of cementation on impoundment stability), geomorphology (e.g., the effects of changing flood occurrence on the remobilisation of contaminated floodplain sediments), mineralogy (e.g., the secondary mineral contaminant-sink assemblage), chemistry (e.g., the influence of oxidation on particular minerals) and toxicology (e.g., quantifying the role of the wind as a contaminant vector) is required.

Finally, this review has made some reference to financial constraints placed on the issues that surround tailings management. Of course, it must be borne in mind that society demands ever increasing quantities of the metals and energy resources, and that this demand is met by the extractive industries. It may be, however, that the accounting practices applied to the individual companies concerned do not provide a full and accurate assessment of the potential environmental cost and risk of tailings dam failure. In accounting terms tailings are essentially defined as a 'hidden flow' which do not enter the economy (Lange and Dept, 2003). The temptation has, therefore, been for tailings handling protocol by individual extractive companies to predominantly emphasis fiscal considerations, perhaps at the expense of safety and environmental considerations. It is also towards the combating of any residual sentiment towards the former approach that this review is also addressed.

\section{Acknowledgements}

Funding for this review was provided through a Birkbeck University of London Research Studentship and a CASE award from The Natural History Museum. MGM's research was supported by the Centre for Catchment and Coastal Research, Aberystwyth University, and by the EU FP7 UMBRELLA project.

\section{References}


Alexander, D., 1986. Northern Italian dam failure and mudflow, July 1985. Disasters 10, 3-7.

Álvarez-Valero, A, Sáez, R, Pérez-López, R, Delgado, J, Nieto, J.M., 2009. Evaluation of heavy metal bio-availability from Almagrera pyrite-rich tailings dam (Iberian Pyrite Belt, SW Spain) based on a sequential extraction procedure. J. Geochem. Explor. 102, 87-94.

Anonymous, 2000. Rain, design flaws contribute to Romanian tailings dam failure. Mining Engineering 52, 6 .

Atkins, P., 1995. Physical Chemistry. Oxford University Press, Oxford.

Azapagic, A., 2004. Developing a framework for sustainable development indicators for the mining and minerals industry. J. Cleaner Prod. 12, 639-662.

Banerjee, J., 2014. 5 Industrial disasters and their costs. Forbes India Magazine, 21 March 2014. http://forbesindia.com/printcontent/37367 (accessed 23/05/2014).

Barton, D.R., Wallace, R.R., 1979. The effects of an experimental spillage of oil sands tailings sludge on benthic invertebrates. Environ. Pollut. 18, 305-312.

Bird, G., Brewer, P.A., Macklin, M.G., Serban, M., Balteanu, D., Driga, B., Zaharia, S., 2008. River system recovery following the Novaţ-Roşu tailings dam failure, Maramureş County, Romania. Appl. Geochem. 23, 3498-3518.

Bjelkevik, A., 2005. Water cover closure design for tailings dams: state of the art report. http:/wpub.ltu.se/1402-1528/2005/19/LTU-FR-0519-SE.pdf (accessed 21/11/2012).

Blas, J., Bream, R., 2008. Chinese agree 96\% jump in ore prices. Financial Times, London, 31 July 2008.

Blowes, D.W., Ptacek, C.J., Jambor, J.L., Weisener, C.G., 2003. The Geochemistry of Acid Mine Drainage. In Lollar, B.S. (Ed.), Environmental Geochemistry. Holland, H.D., Turekian, K.T. (Exec. Eds.) Treatise on Geochemistry, vol. 9, Pergamon, Oxford, pp. 149-204. 
Bobos, I., Durães, N., Noronha, F., 2006. Mineralogy and geochemistry of mill tailings impoundments from Algares (Aljustrel), Portugal: Implications for acid sulfate mine waters formation. J. Geochem. Explor. 88, 1-5.

Brugge, D., Delemos, J.L., Bui, C., 2007. The Sequoyah Corporation fuels release and the Church Rock spill: unpublicized nuclear releases in American Indian communities. Am. J. Public Health $97,1595-1600$.

Bussière, B., Gavin, K., Lehane, B., Ghembaza, M., Taïbi, S., Fleureau, J., Diederichs, M., Côté, J., Konrad, J., Wang, F., Colloquium 2004, 2007. Hydrogeotechnical properties of hard rock tailings from metal mines and emerging geoenvironmental disposal approaches. Can. Geotech. J. 44, 1019-1052.

Byrne, P.M., Seid-Karbasi, M., 2003. Seismic stability of impoundments. $17^{\text {th }}$ Annual Symposium, VGS.

Castro, G., Troncoso, J.H., 1989. Effects of 1985 Chilean earthquake on three tailings dams. $5^{\text {a }}$ Jornada Chilena de Sismología e Ingeniería Sísmica, Chile.

Castro-Larragoitia, J., Kramar, U., Puchelt, H., 1997. 200 years of mining activities at LaPaz/SanLuis Potosí/Mexico — Consequences for environment and geochemical exploration. J. Geochem. Explor. 58, 81-91.

Chakraborty, D., Choudhury, D., 2009. Investigation of the behavior of tailings earthen dam under seismic conditions. Am. J. Eng. Appl. Sci. 2, 559-564.

Chandler, R.J., Tosatti, G., 1996. The Stava tailings dams failure, Italy, July 1985. In: Proceedings ICE: Geotechnical Engineering 113, 1995, pp. 67-79.

Cheng, H., Hu, Y., Luo, J., Xu, B., Zhao, J., 2009. Geochemical processes controlling fate and transport of arsenic in acid mine drainage (AMD) and natural systems. J. Hazard Mat. 165, 1326.

Cheshire, L., 2010. A corporate responsibility? The constitution of fly-in, fly-out mining companies 
as governance partners in remote, mine-affected localities. J. Rural Studies 26, 12-20.

Concas, A., Ardau, C., Cristini, A., Zuddas, P., Cao, G., 2006. Mobility of heavy metals from tailings to stream waters in a mining activity contaminated site. Chemosphere 63, 244-253.

Corriveau, M.C., Jamieson, H.E., Parsons, M.B., Campbell, J.L., Lanzirotti, A., 2011. Direct characterization of airborne particles associated with arsenic-rich mine tailings: Particle size, mineralogy and texture. Appl. Geochem. 26, 1639-1648.

Coulthard, T.J., Macklin, M.G., 2003. Modelling long-term contamination in river systems from historical metal mining. Geology 31, 451-454.

Csavina, J., Field, J., Taylor, M.P., Gao, S., Landázuri, A., Betterton, A.E., Sáez, A.E., 2012. A review on the importance of metals and metalloids in atmospheric dust and aerosol from mining operations. Sci. Total Environ. 433, 58-73.

Dang, Z., Liu, C., Haigh, M.J., 2002. Mobility of heavy metals associated with the natural weathering of coal mine spoils. Environ. Pollut. 118, 419-426.

David, C.P., 2003. Heavy metal concentrations in growth bands of corals: a record of mine tailings input through time (Marinduque Island, Philippines). Marine Pollut. Bull. 46, 187-196.

Davies, M., 2001. Impounded mine tailings: What are the failures telling us? Can. Min. Metall. Bull. 94, 53-59.

Davies, M., 2002. Tailings impoundment failures: are geotechnical engineers listening? Geotech. News 20, 31-36.

Davies, M., Martin, T., 2009. Mining market cycles and tailings dam incidents. In Proceedings of the 13th International Conference on Tailings and Mine Waste, 1-4 November 2009, Banff, Alberta, Canada.

Davies, M., Martin, T., Lighthall, P., 2000. Mine tailings dams: When things go wrong. Tailings Dams 2000, Association of State Dam Safety Officials, U.S. Committee on Large Dams, Las Vegas, Nevada, pp. 261-273. 
Dennis, I.A., Macklin, M.G., Coulthard, T.J., Brewer, P.A., 2003. The impact of the OctoberNovember 2000 floods on contaminant metal dispersal in the River Swale catchment, North Yorkshire, UK. Hydrol. Proc. 17, 1641-1657.

Dennis, I.A., Coulthard, T.J., Brewer, P.A., Macklin, M.G., 2009. The role of floodplains in attenuating contaminated sediment fluxes in formerly mined drainage basins. Earth Surf. Proc. Landforms 34, 453-466.

Diehl, S.F., Goldhaber, M.B., Koenig, A.E., Lowers, H.A., Ruppert, L.F., 2012. Distribution of arsenic, selenium, and other trace elements in high pyrite Appalachian coals: Evidence for multiple episodes of pyrite formation. Int. J. Coal Geol. 94, 238-249.

Dillon, M., White, R., Power, D., 2004. Tailings storage at Lisheen Mine, Ireland. Min. Eng. 17, 123-130.

Dixon-Hardy, D.W., Engels, J.E., 2007. Methods for the disposal and storage of mine tailings. Land Contam. Reclam. 15, 301-317.

Dobry, R., Alvarez, L., 1967. Seismic failures of Chilean tailings dams. J. Soil Mechan. Found. Div, ASCE 93(SM6), 237-260.

Domènech, C., Ayora, C., De Pablo, J., 2002a. Sludge weathering and mobility of contaminants in soil affected by the Aznalcóllar tailing dam spill (SW Spain). Chem. Geol. 190, 355-370.

Domènech, C., de Pablo, J., Ayora, C., 2002b. Oxidative dissolution of pyritic sludge from the Aznalcóllar mine (SW Spain). Chem. Geol. 190, 339-353.

Edwards, R., 1996. Toxic sludge flows through the Andes. New Scientist 152, 4.

Engels, J.E., Dixon-Hardy, D.W., 2008. Tailings Info. http://www.tailings.info (accessed 21/11/2012).

Eriksson, N., Adamek, P., 2000. The tailings pond failure at the Aznalcóllar mine, Spain. Environmental issues and management of waste in energy and mineral production: proceedings 
of the Sixth International Conference on Environmental Issues and Management of Waste in Energy and Mineral Production: SWEMP 2000; Calgary, Alberta, Canada, May 30-June 2, 2000. Filella, M., Belzile, N., Chen, Y.W., 2002. Antimony in the environment: a review focused on natural waters: I. Occurrence. Earth-Sci. Rev. 57, 125-176.

Fipps, G., 1996. Irrigation water quality standards and salinity management strategies. Texas agricultural extension services, Texas A \& M University System, College Station, Tx, USA. http://repository.tamu.edu/bitstream/handle/1969.1/87829/pdf_94.pdf?sequence=1 (accessed $13 / 2 / 2014)$

Foulds, S.A., Brewer, P.A., Macklin, M.G., Haresign, W., Betson, R.E., Rassner, S.M.E., 2014. Flood-related contamination in catchments affected by historical metal mining: an unexpected and emerging hazard of climate change. Sci. Total Environ. 476-477, 165-180.

Fourie, A.B., Blight, G.E, Papageorgiou, G., 2001. Static liquefaction as a possible explanation for the Merriespruit tailings dam failure. Can. Geotech. J. 38, 707-719.

Förstner, U., 1999. Introduction. In Azcue, J.M. (Ed.) Environmental Impacts of Mining Activities: Emphasis on Mitigation and Remedial Measures. Springer, Heidelberg, pp. 1-3.

Fyfe, W., 1981. The environmental crisis: quantifying geosphere interactions. Science 213, 105.

Gamarra, J.G.P., Brewer, P.A., Macklin, M.G., Martin, K., 2013. Modelling remediation scenarios in historically mined catchments. Environ. Sci. Pollut. Res., DOI 10.1007/s11356-013-2170-3

Garcia-Guinea, J., Harffy, M., 1998. Bolivian mining pollution: past, present and future. Ambio 27, $251-253$

Gioda, A., Serrano, C., Forenza, A., 2002. Les ruptures de barrages dans le monde: un nouveau bilan de Potosi (1626, Bolivie). La Houille Blanche 4-5, 165-170.

Giurco, D., 2010. Peak Minerals in Australia: A Review of changing impacts and benefits. Institute for Sustainable Futures, University of Technology, Sydney; Department of Civil Engineering, Monash University. 
Gleisner, M., Herbert, R.B., 2002. Sulfide mineral oxidation in freshly processed tailings: batch experiments. J. Geochem. Explor. 76, 139-153.

Gonzalez, M.J., Fernandez, M., Hernández, L.M., 1990. Influence of acid mine water in the distribution of heavy metal in soils of Donana National Park. Application of multivariate analysis. Environ. Technol. 11, 1027-1038.

Graf, W.L., 1990. Fluvial dynamics of thorium - 230 in the Church Rock Event, Puerco River, New Mexico. Ann. Assoc. Am. Geog. 80, 327-342.

Grimalt, J.O., Ferrer, M., Macpherson, E., 1999. The mine tailing accident in Aznalcollar. Sci. Total Environ. 242, 3-11.

Gulson, B.L., Howarth, D., Mizon, K.J., Law, A.J., Korsch, M.J., Davis, J.J., 1994. Source of lead in humans from Broken Hill mining community. Environ. Geochem. Health 16, 19-25.

Gupta, D.C., 1999. Environmental aspects of selected trace elements associated with coal and natural waters of Pench Valley coalfield of India and their impact on human health. Int. J. Coal Geol. 40, 133-149.

Hellström, L., Persson, B., Brudin, L., Grawé, K.P., Öborn, I., Järup, L., 2007. Cadmium exposure pathways in a population living near a battery plant. Sci. Total Environ. 373, 447-455.

Hilson, G., 2006. Abatement of mercury pollution in the small-scale gold mining industry: Restructuring the policy and research agendas. Sci. Total Environ. 362, $1-14$.

Hizal, J., Tutem, E., Guclu, K., Hugul, M., Ayhan, S., Apak, R., Kilinckale, F., 2013. Heavy metal removal from water by red mud and coal fly ash: an integrated adsorption - solidification / stabilization process. Desalination Water Treatment 51, 7181-7193.

Hoskin, W.A.N.D.A., 2003. Abandoned Mine Sites: Problems, Issues and Options. In Puura, E., Marmo, L., D’Alessandro, M. (Eds.) Workshop on Mine and Quarry Waste - The Burden from the Past. Workshop organised in the frame of the JRC enlargement project: Inventory, 
regulations and environmental impact of toxic mining wastes in pre-accession countries "PECOMINES", 27th-28th May 2002, Ortno, Italy, pp. 53-55.

Hudson, C., 2001. Role of international environmental law in the protection of the Danube River Basin: The Baia Mare Cyanide Spill. Colorado J. Int. Environ. Law Policy 12, 367-393.

Hudson-Edwards, K.A., Jamieson, H.E., Charnock, J.M., Macklin, M.G., 2005. Arsenic speciation in waters and sediments of ephemeral floodplain pools, Río Guadiamar, Aznalcóllar, Spain. Chem. Geol. 219, 175-192.

Hudson-Edwards, K.A., Macklin, M.G., Jamieson, H.E., Brewer, P., Coulthard, T.J., Howard, A.J., Turner J., 2003. The impact of tailings dam spills and clean-up operations on sediment and water quality in river systems: the Ríos Agrio-Guadiamar, Aznalcóllar, Spain. Appl. Geochem. 18, 221-239.

Hudson-Edwards, K.A., Macklin, M.G., Miller, J.R., Lechler, P.J., 2001. Sources, distribution and storage of heavy metals in the Rio Pilcomayo, Bolivia. J. Geochem. Explor. 72, 229-250.

Hudson-Edwards, K.A., Macklin, M.G., Brewer, P.A., Dennis, I.A., 2008. Assessment of metal mining-contaminated river sediments in England and Wales. The Environment Agency. https://www.gov.uk/government/uploads/system/uploads/attachment_data/file/291646/scho1108 bozd-e-e.pdf

Hustrulid, W., 2000. Slope stability in surface mining. Soc. Mining Metall., Colorado, 442 p.

ICOLD, 2001. Tailings Dams: Risk of Dangerous Occurrences and Lessons Learnt from Practical Experiences. Bulletin 121. Joint publication of the International Commission on Large Dams and the United Nations Environmental Programme, Paris.

Jia, Y., Demopoulos, G.P., 2005. Adsorption of arsenate onto ferrihydrite from aqueous solution: influence of media (sulfate vs nitrate), added gypsum, and pH alteration. Environ. Sci. Technol. $39,9523-9527$. 
Kasperski. K.L., Mikula. R.J., 2011. Waste streams of mine oil sands: characteristics and remediation. Elements 7, 387-392.

Keith, C., Vaughan, D.J., 2000. Mechanisms and rates of sulphide oxidation in relation to the problems of acid rock (mine) drainage. In: Cotter-Howells, J.D., Campbell, L.S., Valsami-Jones, E., Batchelder, M. (Eds.) Environmental Mineralogy: Microbial Interactions, Anthropogenic Influences, Contaminated Land and Waste Management. Mineralogical Society Series, 9, pp. 117-139.

Klebercz, O., Mayes, W.M., Anton, Á.D., Feigl, V., Jarvis, A.P., Gruiz, K., 2012. Ecotoxicity of fluvial sediments downstream of the Ajka red mud spill, Hungary. J. Environ. Monitor. 14, 2063-2071.

Kontopoulos, A., Komnitsas, K., Xenidis, A., Papassiopi, N., 1995. Environmental characterisation of the sulphidic tailings in Lavrion. Miner. Eng. 8, 1209-1219.

Kossoff, D., Hudson-Edwards, K.A., Dubbin, W.E., Alfredsson, M.A., 2011. Incongruent weathering of $\mathrm{Cd}$ and $\mathrm{Zn}$ from mine tailings: a column leaching study. Chem. Geol. 281, 52-71.

Kossoff, D., Hudson-Edwards, K.A., Dubbin, W.E., Alfredsson, M., 2012a. Major and trace metal mobility during weathering of mine tailings: implications for floodplain soils. Appl. Geochem. $27,562-576$.

Kossoff, D., Hudson-Edwards, K.A., Dubbin, W.E., Alfredsson, M. 2012b. Cycling of As, P, Pb and $\mathrm{Sb}$ during weathering of mine tailings: implications for fluvial environments. Miner. Mag. $76,1209-1228$.

Koziell, I., Omosa, E., 2003. Room to Manoeuvre? Mining, Biodiversity and Protected Areas. International Institute for Environment and Development and World Council for Sustainable Development, London.

Lange, G., Dept, W.B.E., 2003. Policy applications of environmental accounting. World Bank, Environment Dept., 
https://www.elaw.org/system/files/Policy.Applications.Environmental.Accounting.pdf (accessed 21/11/2012).

Lásló, F., 2006. Lessons learned from the cyanide and heavy metal accidental water pollution in the Tisa River basin in the year 2000. In Dura, G., Simeonova, F. (Eds.), Management of Intentional and Accidental Water Pollution, pp. 43-50.

Lewin, J., Macklin, M.G., 1987. Metal mining and floodplain sedimentation in Britain. In Gardiner V. (Ed.), First International Conference on Geomorphology 1986, Chichester, Wiley, pp. 10091027.

Li, S., Xiao, T., Zheng, B., 2012. Medical geology of arsenic, selenium and thallium in China. Sci. Total Environ. 421, 31-40.

Liu, H., Probst, A., Liao, B., 2005. Metal contamination of soils and crops affected by the Chenzhou lead/zinc mine spill (Hunan, China). Sci. Total Environ. 339, 153-166.

López-Pamo, E., Barettino, D., Antón-Pacheco, C., Ortiz, G., Arránz, J.C., Gumiel, J.C., MartínezPledel, B., Aparicio, M., Montouto, O., 1999. The extent of the Aznalcóllar pyritic sludge spill and its effects on soils. Sci. Total Environ. 242, 57-88.

Lottermoser, B., 2007. Mine Wastes: Characterization, Treatment and Environmental Impacts. Springer, Berlin, Heidelberg, New York.

Lottermoser, B.G., Ashley, P.M., 2005. Tailings dam seepage at the rehabilitated Mary Kathleen uranium mine, Australia. J. Geochem. Explor. 85, 119-137.

Lucas, C., 2001. The Baia Mare and Baia Borsa accidents: cases of severe transboundary water pollution. Environmental Policy and Law, 31, 106-111.

Ma, G., Rengasamy, P., Rathjen, A.J., 2003. Phytotoxicity of aluminium to wheat plants in high-pH solutions. Aust. J. Exper. Agr. 43, 497-501.

Macklin, M.G., 1996. Fluxes and storage of sediment-associated metals in floodplain systems: assessment and river basin management issues at a time of rapid environmental change. In 
Anderson, M.G., Walling, D.E., Bates, P. (Eds.), Floodplain Processes, Chichester, Wiley, pp. 441-460.

Macklin, M.G., Payne, I., Preston, D., Sedgwick, C., 1996. Review of the Porco Mine Tailings Dam Burst and Associated Mining Waste Problems, Pilcomayo Basin, Bolivia. Report to UK Overseas Development Association.

Macklin, M.G., Brewer, P.A., Balteanu, D., Coulthard, T.J., Driga, B., Howard, A.J., Zaharia, S., 2003. The long term fate and environmental significance of contaminant metals released by the January and March 2000 mining tailings dam failures in Maramures County, upper Tisa Basin, Romania. Appl. Geochem. 18, 241-257.

Macklin M.G., Brewer P.A., Hudson-Edwards, K.A., Bird, G., Coulthard T.J., Dennis, I.A., Lechler, P.J., Miller, J.R., Turner, J.N., 2006. A geomorphological approach to the management of rivers contaminated by metal mining. Geomorphology 79, 423-447.

Madejón, P., Pérez de Mora, A., Burgos, P., Cabrera, F., Lepp, N.W., Madejón, E., 2010. Do amended, polluted soils require re-treatment for sustainable risk reduction? - Evidence from field experiments. Geoderma 159, 174-181.

Mahrla, H., 2011. Tailing dams. Infrassure Quarterly, Issue 17, May 2011.

Martin. T.E., Davies, M.P., 2000. Trends in the stewardship of tailings dams. In: Proceedings of Tailings and Mine Waste'00, Fort Collins, January, Balkema Publishers, pp. 393-407.

Martin, T.E., McRoberts, E.C., 1999. Some considerations in the stability analysis of upstream tailings dams. Proc. Tailings \& Mine Waste'99, pp. 287-302.

Martin, T.E., McRoberts, E.C., Davies, M.P., 2002. A tale of four upstream tailings dams. Proc. Tailings Dams 2002, ASDSO/USCOLD.

Mason, L., Prior, T.D., Mudd, G.M., Giurco, D., 2010. Availability, addiction and alternatives: three criteria for assessing the impact of peak minerals on society. J. Cleaner Prod. 19, 958-966. 
Mayes, W.M., Jarvis, A.P., Burke, I.T., Walton, M., Feigl, V., Klebercz, O., Gruiz, K., 2011. Dispersal and attenuation of trace contaminants downstream of the Ajka bauxite residue (red mud) depository failure, Hungary. Environ. Sci. Technol. 45, 5147-5155.

McLean, I., Johnes, M., 2000. Aberfan: Government and Disasters. Welsh Academic Press, Cardiff. Meck, M., Love, D., Mapni, B., 2006. Zimbabwean mine dumps and their impacts on river water quality: a reconnaissance study. Phys. Chem. Earth. Pts A/B/C/ 31, 797-803.

Mehrabani, J.V., Noaparast, M., Mousavi, S.M., Dehghan, R., Ghorbani, A., 2010. Process optimization and modelling of sphalerite flotation from a low-grade $\mathrm{Zn}-\mathrm{Pb}$ ore using response surface methodology. Separation Purification Technol. 72, 242-249.

Mileusnić, M., Mapani, B.S., Kamona, A.F., Ružičić, S., Mapaure, I., Chimwamurombe, P.M., 2014. Assessment of agricultural soil contamination by potentially toxic metals dispersed from improperly disposed tailings, Kombat mine, Namibia. J. Geochem. Explor. in press.

Miller, J.R., Hudson-Edwards, K.A., Lechler, P.J., Preston, D., Macklin, M.G., 2004. Heavy metal contamination of water, soil and produce within riverine communities of the Río Pilcomayo basin, Bolivia. Sci. Total Environ. 320, 189-209.

Mulligan, D.R., 1996. Environmental Management in the Australian Minerals and Energy Industry. University of New South Wales Press, Sydney.

Müller, J., Frimmel, H.E., 2010. Numerical analysis of historic gold production cycles and implications for future sub-cycles. Open Geol. J. 4, 29-34.

Nikiforuk, A., 2010. Tar Sands: Dirty Oil and the Future of a Continent. Greystone Books, Vancouver.

Olías, M., Nieto, J.M., Sarmiento, A.M., Cerón, J.C., Cánovas, C.R., 2004. Seasonal water quality variations in a river affected by acid mine drainage: the Odiel River (South West Spain). Sci. Total Environ. 333, 267-281. 
Olías, M., Moral, F., Galván, L., Cerón, J.C., 2012. Groundwater contamination evolution in the Guadiamar and Agrio aquifers after the Aznalcóllar spill: assessment and environmental implications. Environ. Monit. Assess. 184, 3629-3641.

Prakash, S., Guo, T., Kumar, S., 1998. Liquefaction of silts and silt-clay mixtures. Geotech. Spec. Publ. 75, 337-348.

Psarropoulos, P.N., Tsompanakis, Y., Karabatsos, Y., Xiroudakis, G., Sarris, E., 2005. Stability of tailings dams-Part II: dynamic loading. International Workshop in Geoenvironment and Geotechnics, September 2005, Milos Island, Greece, pp. 37-44.

Puro, M.J., Kipkie, W.B., Knapp, R.A., McDonald, T.J., Stuparyk, R.A., 1995. Inco’s Copper Cliff tailings area. Proceedings of the Sudbury'95 Conference on Mining and the Environment, pp. 181-191.

Rabinowitz, M.B., 2005. Lead isotopes in soils near five historic American lead smelters and refineries. Sci. Total Environ. 346, 138-148.

Ramos, L., Hernandez, L.M., Gonzalez, M.J., 1994. Sequential fractionation of copper, lead, cadmium and zinc in soils from or near Doñana National Park. J. Environ. Qual. 23, 50-57.

Rees, K.L., Van Deventer, J.S.J., 1999. The role of metal-cyanide species in leaching gold from a copper concentrate. Miner. Eng. 12, 877-892.

Renforth, P., Mayes, W.M., Jarvis, A.P., Burke, I.T., Manning, D.A.C., Gruiz, K., 2012. Contaminant mobility and carbon sequestration downstream of the Ajka (Hungary) red mud spill: the effects of gypsum dosing. Sci. Total Environ. 421-422, 253-259.

Rico, M., Benito, G., Díez-Herrero, A., 2008a. Floods from tailings dam failures. J. Hazard. Mat. 154, 79-87.

Rico, M., Benito, G., Salgueiro, A.R., Díez -Herrero A., Pereira, H.G., 2008b. Reported tailings dam failures: a review of the European incidents in the worldwide context. J. Hazard Mat. 152, 846-852. 
Robb, L., 2004. Introduction to Ore-forming Processes. Wiley-Blackwell, Oxford.

Rodríguez, L., Ruiz, E., Alonso-Azcárate, J., Rincón, J., 2009. Heavy metal distribution and chemical speciation in tailings and soils around a $\mathrm{Pb}-\mathrm{Zn}$ mine in Spain. J. Environ. Monitor. 90, 1106-1116.

Rogovin, M., 1979. Three Mile Island: A Report to the Commissioners and to the Public. Nuclear Regulatory Commission, Washington, DC (USA).

Romano, C.G., Mayer, K.U., Jones, D.R., Ellerbroek, D.A., Blowes, D.W., 2003. Effectiveness of various cover scenarios on the rate of sulfide oxidation of mine tailings. J. Hydrol. 271, 171-187.

Rudolph, T., Coldewey, W., 1971. Implications of earthquakes on the stability of tailings dams. http://www.pebblescience.org/OLD-SITE/pdfs/Tailings_dam.pdf (accessed 5/12/2012)

Rudolph, W., 1936. The lakes of Potosí. Geograph. Rev. 26, 529-554.

Ruhl, L., Vengosh, A., Dwyer, G.S., Hsu-Kim, H., Deonarine, A., Bergin, M., Kravchenko, J., 2009. Survey of the potential environmental and health impacts in the immediate aftermath of the coal ash spill in Kingston, Tennessee. Environ. Sci. Technol. 43, 6326-6333.

Rutley, F., Read, H.H., 1970. Rutley's Elements of Mineralogy. T. Murby \& Company, London.

Ruyters, S., Mertens, J., Vassilieva, E., Dehandschutter, B., Poffijn, A., Smolders, E., 2011. The red mud accident in Ajka (Hungary): plant toxicity and trace metal bioavailability in red mud contaminated soil. Environ. Sci. Technol. 45, 1616-1622.

Salvarredy-Aranguren, M.M., Probst, A., Roulet, M., Isaure, M.-P., 2008. Contamination of surface waters by mining wastes in the Milluni Valley (Cordillera Real, Bolivia): Mineralogical and hydrological influences. Appl. Geochem. 23, 1299-1324.

Sarsby, R.W., 2000. Environmental Geotechnics. Thomas Telford, London.

Seal II, R.R., Hammarstrom, J.M., Johnson, A.N., Piatak, N.M., Wandless, G.A., 2008.

Environmental geochemistry of a Kuroko-type massive sulfide deposit at the abandoned Valzinco mine, Virginia, USA. Appl. Geochem. 23, 320-342. 
Simón, M., Ortiz, I., Garcıa, I., Fernández, E., Fernández, J., Dorronsoro, C., Aguilar, J., 1999. Pollution of soils by the toxic spill of a pyrite mine (Aznalcóllar, Spain). Sci. Total Environ. 242, $105-115$.

Smith, A.M.L., Dubbin, W.E., Wright, K., Hudson-Edwards, K.A., 2006. Dissolution of lead-and lead-arsenic jarosites at pH 2 and 8 and $20^{\circ} \mathrm{C}$ : Insights from batch experiments. Chem. Geol. $229,344-361$.

Smuda, J., Dold, B., Spangenberg, J.E., Friese, K., Kobek, M.R., Bustos, C.A., Pfeifer, H.R., 2014. Element cycling during the transition from alkaline to acidic environment in an active porphyry copper tailings impoundment, Chuquicamata, Chile. J. Geochem. Explor. in press.

Soares, L., Arnez, F.I., Hennies, W.T., 2000. Major causes of accidents in tailing dam due to geological and geotechnical factors. Mine Planning and Equipment Selection - International Symposium, pp. 371-376.

Shackelford, C.D., Sevick, G.W., Eykholt, G.R., 2010. Hydraulic conductivity of geosynthetic clay liners to tailings impoundment solutions. Geotextiles Geomembranes 28, 149-162.

Shraim, A., Cui, X., Li, S., Ng, J. C., Wang, J., Jin, Y., Liu, Y., Guo, L., Li, D., Wang, S., 2003. Arsenic speciation in the urine and hair of individuals exposed to airborne arsenic through coalburning in Guizhou, PR China. Toxicol. Lett. 137, 35-48.

Smolders, A., de Smolders, L., 1998. La contaminación del rio Pilcomayo y el pez sábalo (Prochilodus lineatus) con metales pesados. Report to Universidad Católica de Nijmegen (Holanda), Universidad Autónoma Juan Misael Saracho (Tarija) and Ambio Chaco (Villa Montes).

Smolders, A.J.P., Guerrero Hiza, M.A, Van der Velde, G., Roelofs, J.G.M., 2002. Dynamics of discharge, sediment transport, heavy metal pollution and sábalo (Prochilodus lineatus) catches in the Lower Pilcomayo River (Bolivia). Riv. Res. Appl. 18, 415-427. 
Smolders, A.J., Lock, R.A., Van der Velde, G., Medina Hoyos, R.I., Roelofs, J.G., 2003. Effects of mining activities on heavy metal concentrations in water, sediment, and macroinvertebrates in different reaches of the Pilcomayo River, South America. Arch. Environ. Contam. Toxicol. 44, 314-323.

Stiller, D., 2000. Wounding the West: Montana, Mining, and the Environment. University of Nebraska Press.

Strosnider, W.H., Llanos, F., Nairn, R.W., 2008. A legacy of nearly 500 years of mining in Potosí, Bolivia: stream water quality. In Proceedings, 2008 National Meeting of the American Society of Mining and Reclamation, Richmond, VA.

Troncoso, J.H., 1990. Failure risks of abandoned tailings dams. Proc. Int. Symp. on Safety and Rehabilitation of Tailings Dams, Int. Commission on Large Dams, Paris, pp. 82-89.

Turner, J.N., 2003. A geomorphological-geochemical assessment of the impact of the Aznalcóllar tailings dam failure on the Río Guadiamar, southwest Spain. PhD dissertation. University of Wales Aberystwyth, UK, 318 pp.

Turner, J.N., Brewer, P.A., Macklin, M.G., Hudson-Edwards, K.A., Coulthard, T.J., Howard, A.J., Jamieson, H.E., 2002. Heavy metal and As transport under low and high flows in the River Guadiamar three years after the Aznalcollar tailings dam failure: implications for river recovery and management. In García-Ruiz, J.M., Jones, J.A.A., Arnáez, J. (Eds.) Environmental Change and Water Sustainability. Instituto Pirenaico de Ecologiá, Zaragoza.

Turner, J.N., Brewer, P.A., Macklin, M.G., 2008. Fluvial-controlled metal and As mobilisation, dispersal and storage in the Río Guadiamar, SW Spain and its implications for long-term contaminant fluxes to the Doñana wetlands. Sci. Total Environ. 394, 144-161.

United States Committee On Large Dams (USCOLD), 1994. Tailings Dam Incidents. A report prepared by the USCOLD Committee on Tailings Dams, http://ussdams.org/pubs.html (accessed 21/11/2012). 
United States Environmental Protection Agency, 1994. Technical report design and evaluation of tailings dams. http://www.epa.gov/osw/nonhaz/industrial/special/mining/techdocs/tailings.pdf (accessed 21/11/2012).

United States Environmental Protection Agency, 2002. Risk Assessment: Technical Background Information. RBG Table, http://www.epa.gov/safewater/contaminants/index.html\#inorganic. (accessed 25/1/2014).

United States Environmental Protection Agency Region 6 Congressional District 03, 2010. United Nuclear Cooperation, McKinley, New Mexico. http://www.epa.gov/region6/6sf/pdffiles/0600819.pdf (accessed 21/3/2012).

Vandeberg, G.S., Martin, C.W., Pierzynski, G.M., 2011. Spatial distribution of trace elements in floodplain alluvium of the upper Blackfoot River, Montana. Environ. Earth Sci. 62, 1521-1534.

Van Niekerk H.J., Viljoen M.J., 2005. Causes and consequences of the Merriespruit and other tailings dam failures. Land Degrad. Develop. 16, 201-212.

Van Zyl, D.J.A., Hutchison, I., Kiel, J., 1988. Introduction to evaluation, design, and operation of precious metal heap leaching projects. Society of Mining Engineers, Littleton, Colorado.

Verdugo, R., Sitar, N., Frost, J.D., Bray, J.D., Candia, G., Eldridge, T., Hashash, Y., Olson, S.M., and Urzua, A., 2012. Seismic Performance of Earth Structures during the February 2010 Maule, Chile, Earthquake: Dams, Levees, Tailings Dams, and Retaining Walls. Earthquake Spectra 28, S75-S96.

Vick, S.G., 1983. Planning, Design, and Analysis of Tailings Dams. Wiley, New York.

Villarroel, L.F, Miller, J.R., Lechler, P.J., Germanoski, D., 2006. Lead, zinc, and antimony contamination of the Rio Chilco-Rio Tupiza drainage system, Southern Bolivia. Environ. Geol. 51, 283-299.

Willis, 2012. Mining Market Review. Willis Limited, London. 
World Health Organization, 1993. Guidelines for drinking water quality. Recommendations, 2nd edition, http://www.who.int/water_sanitation_health/dwq/gdwq2v1/en/ (accessed 27/1/2014).

World Health Organization, 2006. Guidelines for drinking water quality. Recommendations, 3rd edition, http://www.who.int/water_sanitation_health/dwq/gdwq3rev/en// (accessed 27/1/2014).

WISE World Information Service on Energy Uranium Project, 2012. Chronology of major tailings dam failures, http://www.antenna.nl/wise/uranium/mdaf.html (accessed 12/11/2012).

WISE World Information Service on Energy Uranium Project, 2013. The Los Frailes tailings dam Failure (Aznalcóllar, Spain). http://www.wise-uranium.org/mdaflf.html (accessed 23/05/2014).

WISE World Information Service on Energy Uranium Project, 2014. Chronology of major tailings dam failures. http://www.wise-uranium.org/mdaf.html (accessed 23/05/2014).

Ye, Z.H., Shu, W.S., Zhang, Z.Q., Lan, C.Y., Wong, M.H., 2002. Evaluation of major constraints to revegetation of lead/zinc mine tailings using bioassay techniques. Chemosphere 47, 1103-1111.

Younger, P.L., Wolkersdorfer C., 2004. Mining impacts on the fresh water environment: technical and managerial guidelines for catchment scale management. Mine Water Environ. 23, 2-80.

Xiao, T., Guha, J., Boyle, D., Liu, C.Q., Zheng, B., Wilson, G.C., Rouleau, A., Chen, J., 2004. Naturally occurring thallium: a hidden geoenvironmental health hazard? Environ. Int. 30, 501507.

Zhang, Z., Zhang, B., Long, J., Zhang, X., Chen, G., 1998. Thallium pollution associated with mining of thallium deposits. Science in China Ser. D: Earth Sci. 41, 75-81. 
Table 1. Examples of chemical characteristics of tailings.

\begin{tabular}{|c|c|c|c|c|c|c|c|c|c|c|}
\hline Location & $\begin{array}{l}\text { Aznalcóllar, } \\
\text { Spain }\end{array}$ & $\begin{array}{l}\text { Piscinas, } \\
\text { Sardinia }\end{array}$ & $\begin{array}{c}\text { San Luis, } \\
\text { Potosi, Mexico }\end{array}$ & $\begin{array}{c}\text { Leechang, } \\
\text { China (densely } \\
\text { vegetated) }\end{array}$ & $\begin{array}{c}\text { Lavrion, } \\
\text { Greece (Spoil } \\
\text { B) }\end{array}$ & $\begin{array}{l}\text { Algares, } \\
\text { Portugal }\end{array}$ & Virginia, USA & $\begin{array}{l}\text { Boliden, } \\
\text { Sweden }\end{array}$ & $\begin{array}{l}\text { Milluni, } \\
\text { Bolivia }\end{array}$ & Potosi, Bolivia \\
\hline Reference & $\begin{array}{c}\text { Hudson- } \\
\text { Edwards et al., } \\
2003\end{array}$ & $\begin{array}{c}\text { Concas et al., } \\
2006\end{array}$ & $\begin{array}{c}\text { Castro- } \\
\text { Larragoitia et } \\
\text { al. } 1997\end{array}$ & Ye et al., 2002 & $\begin{array}{c}\text { Kontopoulos et } \\
\text { al., } 1995\end{array}$ & $\begin{array}{c}\text { Bobos et al., } \\
2006\end{array}$ & $\begin{array}{l}\text { Seal II et al., } \\
2008\end{array}$ & $\begin{array}{c}\text { Gleisner and } \\
\text { Herbert, } 2002\end{array}$ & $\begin{array}{l}\text { Salvarredy - } \\
\text { Aranguren et } \\
\text { al., } 2008\end{array}$ & $\begin{array}{c}\text { Kossoff et al., } \\
2011\end{array}$ \\
\hline Deposit type & poly-sulfide & poly-sulfide & $\begin{array}{l}\text { Au and poly- } \\
\text { sulfde }\end{array}$ & poly-sulfide & poly-sulfide & $\mathrm{Pb} / \mathrm{As}$ sulfide & $\begin{array}{l}\text { Au and poly- } \\
\text { sulfide }\end{array}$ & poly-sulfide & poly-sulfide & poly-sulfide \\
\hline $\begin{array}{l}\text { Number of } \\
\text { samples }\end{array}$ & 11 & not given & not given & average of 5 & not given & average of 15 & average of 7 & not given & not given & 30 \\
\hline \multicolumn{11}{|c|}{ Concentrations in wt. $\%$} \\
\hline $\mathrm{Al}$ & & & & & $1-4$ & & 2.58 & 4.46 & & $3.44 \pm 0.10$ \\
\hline $\mathrm{Ca}$ & & & & & $4-16$ & & 0.06 & 2.18 & & $0.22 \pm 0.02$ \\
\hline $\mathrm{Fe}$ & & 6.5 & & & $3-15$ & & 8.1 & 19.8 & 31.6 & $17.5 \pm 0.55$ \\
\hline $\mathrm{K}$ & & & & & & & 0.99 & 0.685 & & $1.30 \pm 0.04$ \\
\hline $\mathrm{Mg}$ & & & & & & & 0.46 & 4.07 & & $0.08 \pm 0.00$ \\
\hline $\mathrm{Mn}$ & & 0.36 & & & & & 0.06 & 6.39 & 0.0077 & $0.06 \pm 0.00$ \\
\hline $\mathrm{Na}$ & & & & & & & 0.12 & 0.276 & & $0.04 \pm 0.00$ \\
\hline $\mathrm{P}$ & & & & 0.35 & & & & 0.044 & & $0.11 \pm 0.00$ \\
\hline $\mathrm{S}$ & & & & & $2-5$ & & 6.25 & 17.8 & & $19.8 \pm 0.68$ \\
\hline $\mathrm{Si}$ & & & & & & & & 15.7 & & $21.1 \pm 0.6$ \\
\hline $\mathrm{Ti}$ & & & & & & & & 0.196 & & $0.22 \pm 0.01$ \\
\hline \multicolumn{11}{|c|}{ Values in $\mathrm{mg} \mathrm{kg}^{-1}$} \\
\hline $\mathrm{Ag}$ & & & & & & & 60 & & & \\
\hline As & 2,500 & & 4,000 & & $1,000-25,000$ & 1,213 & 25 & 2,960 & 5,600 & $6,960 \pm 452$ \\
\hline $\mathrm{Au}$ & & & 0.7 & & & & & & & \\
\hline $\mathrm{Ba}$ & & & & & & 604 & 200 & 274 & & \\
\hline $\mathrm{Cd}$ & 27 & 71 & 30 & 14 & $50-200$ & & 10 & 16.6 & 118 & $62.1 \pm 5.00$ \\
\hline $\mathrm{Co}$ & & 15 & & & & 106 & 44 & 57.8 & & \\
\hline $\mathrm{Cr}$ & & & & & & 80 & 11 & 36.2 & & \\
\hline $\mathrm{Cu}$ & 1,600 & 84 & 400 & 192 & & 727 & 453 & 640 & 3,550 & $502 \pm 39$ \\
\hline $\mathrm{Hg}$ & & & & & & & & 8.42 & & \\
\hline $\mathrm{La}$ & & & & & & & & 13.7 & & \\
\hline Mo & & & & & & & & $<5.92$ & & \\
\hline $\mathrm{Nb}$ & & & & & & & & 11.9 & & \\
\hline $\mathrm{Ni}$ & 20 & 25 & & & & $<5$ & 10 & 11.3 & & \\
\hline $\mathrm{Pb}$ & 8,500 & 4,100 & 3,000 & 1,642 & $10,000-30,000$ & 6,805 & 3,528 & 1,850 & 846 & $2,180 \pm 120$ \\
\hline $\mathrm{Sb}$ & 270 & & & & & & 8 & & & $723 \pm 63$ \\
\hline $\mathrm{Sc}$ & & & & & & & & 8.8 & & \\
\hline $\mathrm{Sn}$ & & & & & & 136 & & $<23.7$ & & $222 \pm 18$ \\
\hline $\mathrm{Sr}$ & & & & & & & & 43.7 & & \\
\hline $\mathrm{Tl}$ & 56 & & & & & & 10 & & & $9.96 \pm 0.55$ \\
\hline $\mathrm{V}$ & & & & & & 30 & & 40.7 & & \\
\hline $\mathrm{W}$ & & & & & & & & $<59.2$ & & \\
\hline $\mathrm{Y}$ & & & & & & & & 12.2 & & \\
\hline $\mathrm{Zn}$ & 7,400 & 7,300 & 2,000 & 5,021 & $5,000-50,000$ & 3,713 & 2,178 & 5,290 & 26,700 & $26,600 \pm 1,300$ \\
\hline
\end{tabular}


Table 2. Examples of tailings impoundment failures.

\begin{tabular}{|c|c|c|c|c|c|c|}
\hline $\begin{array}{l}\text { Mine (location and } \\
\text { year) and material }\end{array}$ & $\begin{array}{l}\text { Principal mined } \\
\text { ore / process } \\
\text { material } \\
\text { released }\end{array}$ & $\begin{array}{l}\text { Volume of } \\
\text { tailings } \\
\text { released }\end{array}$ & $\begin{array}{l}\text { Active } \\
\text { (A) / } \\
\text { Inactive } \\
\text { (I) }\end{array}$ & Cause & $\begin{array}{l}\text { Dam } \\
\text { raising } \\
\text { method }\end{array}$ & $\begin{array}{l}\text { Immediate } \\
\text { fatalities }\end{array}$ \\
\hline $\begin{array}{l}\text { San Ildfonso, } \\
\text { Potosí ('Bolivia', } \\
1626)^{1)}\end{array}$ & Sulfide / Ag Hg & Unknown & A & Unknown & Unknown & $\sim 4000$ \\
\hline $\begin{array}{l}\text { El Cobre Old } \\
\text { Dam, (Chile, } \\
1965)^{\text {c) }}\end{array}$ & $\mathrm{Cu}$ & $1,900,000$ & A & $\begin{array}{l}\text { Breach following } \\
\text { earthquake }\end{array}$ & Upstream & $>300$ \\
\hline $\begin{array}{l}\text { Church Rock } \\
(\text { New Mexico, } \\
1979)^{k)}\end{array}$ & $\mathrm{U}$ & 400,000 & A & Unknown & Unknown & Unknown \\
\hline $\begin{array}{l}\text { Cerro Negro No. } \\
4, \text { (Chile, 1985) }^{\text {b) }}\end{array}$ & $\mathrm{Cu}$ & $2,000,000$ & A & $\begin{array}{l}\text { Breach following } \\
\text { earthquake }\end{array}$ & Upstream & Unknown \\
\hline $\begin{array}{l}\text { Jinduicheng, } \\
\text { (Shaanxi province, }^{\text {China, 1988) }}\end{array}$ & Mo & 700,000 & A & $\begin{array}{l}\text { Overtopping / } \\
\text { poor } \\
\text { maintenance }\end{array}$ & Upstream & $\sim 20$ \\
\hline $\begin{array}{l}\text { Harmony, } \\
\text { Merriespruit, } \\
\text { (South Africa, } \\
\text { 1994)g) }\end{array}$ & $\mathrm{Au}$ & 600,000 & I & $\begin{array}{l}\text { Breach following } \\
\text { heavy rain / poor } \\
\text { maintenance }\end{array}$ & Upstream & 17 \\
\hline $\begin{array}{l}\text { Stava, (North Italy, } \\
\text { 1995) i) }\end{array}$ & fluorite & 190,000 & A & $\begin{array}{l}\text { Poor } \\
\text { maintenance }\end{array}$ & Upstream & $\sim 250$ \\
\hline $\begin{array}{l}\text { Porco, (Bolivia, } \\
\text { 1996) }\end{array}$ & sulfide & 400,000 & A & $\begin{array}{l}\text { Breach following } \\
\text { heavy rain }\end{array}$ & Upstream & $\begin{array}{l}\text { Possibly } 3 \\
\text { children } \mathrm{m} \text { ) }\end{array}$ \\
\hline $\begin{array}{l}\text { Aznalcóllar, } \\
(\text { Spain, 1998) d) }\end{array}$ & sulfide & $1,300,000$ & A & $\begin{array}{l}\text { Foundation } \\
\text { failure / poor } \\
\text { maintenance }\end{array}$ & Mixed & 0 \\
\hline $\begin{array}{l}\text { Baia Mare and } \\
\text { Baia Borsa, } \\
\text { (Romania, 2000) }^{\mathrm{j})}\end{array}$ & $\mathrm{Ag}, \mathrm{Au} /$ cyanide & $\begin{array}{l}\text { Two } \\
\text { incidents of } \\
100,000\end{array}$ & A & $\begin{array}{l}\text { Breach following } \\
\text { heavy rain and } \\
\text { snow melt }\end{array}$ & Upstream & 0 \\
\hline $\begin{array}{l}\text { Kingston plant, } \\
\text { (Tennessee, USA., } \\
\text { 2008) a) }\end{array}$ & $\begin{array}{l}\text { Coal fly ash/ } \\
{ }^{226} \mathrm{Ra}+{ }^{228} \mathrm{Ra} / \\
\mathrm{As} / \mathrm{Hg}\end{array}$ & $4,100,000$ & A & $\begin{array}{l}\text { Retention wall } \\
\text { failure }\end{array}$ & Upstream & 0 \\
\hline $\begin{array}{l}\text { Ajkai Timfoldgyar } \\
\text { Zrt alumina plant, } \\
(\text { Hungary, 2010) }\end{array}$ & $\mathrm{Al} /$ alkali & $\begin{array}{l}6,000,000- \\
7,000,000\end{array}$ & $\mathrm{~A}$ & Unknown & Unknown & 10 \\
\hline
\end{tabular}

a) Ruhl et al., 2009; b) WISE, 2012; c) Rudolph and Coldewey, 1971; d) Hudson-Edwards et al., 2003; e) Ruyters et al., 2011; f) Davies et al., 2000; g) Fourie et al., 2001; h) Macklin et al., 2006; i) Alexander, 1996; j) Macklin et al., 2003; k) Brugge et al., 2007; 1) Rudolph, 1936; m) GarciaGuinea and Harffy, 1998. 
Table 3. Selected aqueous river water concentrations following tailings dam spills, together with selected advisory maxima for irrigation and drinking water concentrations.

\begin{tabular}{|c|c|c|c|c|c|c|c|}
\hline & $\begin{array}{l}\text { Sampling } \\
\text { date }\end{array}$ & $\begin{array}{l}\text { As } \\
\mathrm{mg} \mathrm{L}^{-1}\end{array}$ & $\begin{array}{l}\mathrm{Cd} \\
\mathrm{mg} \mathrm{L}^{-1}\end{array}$ & $\begin{array}{l}\mathrm{Cu} \\
\mathrm{mg} \mathrm{L}\end{array}$ & $\begin{array}{l}\mathrm{Mn} \\
\mathrm{mg} \mathrm{L} L^{-1}\end{array}$ & $\begin{array}{l}\mathrm{Pb} \\
\mathrm{mg} \mathrm{L}\end{array}$ & $\begin{array}{l}\mathrm{Zn} \\
\mathrm{mg} \mathrm{L} \mathrm{L}^{-1}\end{array}$ \\
\hline $\mathrm{WHO}^{\mathrm{a})}$ & & 0.01 & 0.003 & 2 & 0.4 & 0.01 & 3.0 \\
\hline USEPA $^{b)}$ & & 0.01 & 0.005 & 1.3 & & 0.015 & \\
\hline $\mathrm{R} \& \mathrm{~A}-\mathrm{M}^{\mathrm{c})}$ & & 0.1 & 0.01 & 0.2 & 0.2 & 5.0 & 2.0 \\
\hline \multicolumn{8}{|c|}{$\begin{array}{l}\text { Aznalcóllar, Spain (April 1998) }{ }^{\mathrm{e})} \text { Figures in parenthesis are medians. }{ }^{*} \mu \mathrm{g} \mathrm{L}^{-1} \text { all other } \\
\text { values in } \mathrm{mg} \mathrm{L}^{-1}\end{array}$} \\
\hline $\begin{array}{l}\text { Seven } \\
\text { sampling } \\
\text { sites" near", } \\
\text { the mine }\end{array}$ & $\begin{array}{l}\text { Spill plus } \\
10 \text { days }\end{array}$ & $\begin{array}{l}1.74- \\
4.30 \\
(2.32)^{*}\end{array}$ & $\begin{array}{l}0.64- \\
0.75 \\
(0.65)\end{array}$ & $\begin{array}{l}0.24- \\
0.40 \\
(0.30)\end{array}$ & $\begin{array}{l}10.93- \\
11.56 \\
(11.15)\end{array}$ & $\begin{array}{l}2.05- \\
2.60 \\
(2.15)\end{array}$ & $\begin{array}{l}71.38- \\
74.81 \\
(72.12)\end{array}$ \\
\hline \multicolumn{8}{|c|}{ Kolontar, Hungary $\left.(\text { October } 4,2010)^{\mathrm{g}}\right)$ Figures in parenthesis are filtered to $0.45 \mu \mathrm{m}$} \\
\hline & & $\begin{array}{l}\mathrm{Al} \\
\mathrm{mg} \mathrm{L}^{-1}\end{array}$ & $\begin{array}{l}\text { As } \\
\mu \mathrm{g} \mathrm{L} \mathrm{L}^{-1}\end{array}$ & $\begin{array}{l}\mathrm{Cd} \\
\mu \mathrm{g} \mathrm{L} \mathrm{L}^{-1}\end{array}$ & $\begin{array}{l}\mathrm{Mn} \\
\mu \mathrm{g} \mathrm{L} \mathrm{L}^{-1}\end{array}$ & $\begin{array}{l}\text { Mo } \\
\mu \mathrm{g} \mathrm{L}-1\end{array}$ & $\begin{array}{l}\mathrm{V} \\
\mu \mathrm{g} \mathrm{L} \mathrm{L}^{-1}\end{array}$ \\
\hline $\begin{array}{l}\text { Reference } \\
\text { samples }\end{array}$ & $\begin{array}{l}\text { Spill plus } \\
58 \text { days }\end{array}$ & $\begin{array}{l}0.21 \\
(0.001)\end{array}$ & $<0.1$ & $<0.1$ & $\begin{array}{l}84 \\
(39)\end{array}$ & $\begin{array}{l}19 \\
(11)\end{array}$ & $<1$ \\
\hline $\begin{array}{l}\text { Immediately } \\
\text { adjacent to } \\
\text { dam breech }\end{array}$ & & $\begin{array}{l}1,228 \\
(659)\end{array}$ & $\begin{array}{l}3,926 \\
(3,612 \\
)\end{array}$ & $\begin{array}{l}59 \\
(53)\end{array}$ & $\begin{array}{l}9,894 \\
(<1)\end{array}$ & $\begin{array}{l}5,443 \\
(4,114\end{array}$ & $\begin{array}{l}6,398 \\
(5,709)\end{array}$ \\
\hline $\begin{array}{l}\text { Kolontar } \\
\text { village } \\
\sim 3 \mathrm{~km} \\
\text { downstream }\end{array}$ & & $\begin{array}{l}12.73 \\
(9.02)\end{array}$ & $\begin{array}{l}181 \\
(147)\end{array}$ & $<0.1$ & $\begin{array}{l}77 \\
(8)\end{array}$ & $\begin{array}{l}420 \\
(416)\end{array}$ & $\begin{array}{l}347 \\
(343)\end{array}$ \\
\hline $\begin{array}{l}\mathrm{T} 4 \sim 10 \mathrm{~km} \\
\text { downstream }\end{array}$ & & $\begin{array}{l}4.01 \\
(0.41)\end{array}$ & $\begin{array}{l}43 \\
(4)\end{array}$ & $<0.1$ & $\begin{array}{l}161 \\
(81)\end{array}$ & $\begin{array}{l}83 \\
(78)\end{array}$ & $\begin{array}{l}48 \\
(39)\end{array}$ \\
\hline $\begin{array}{l}\mathrm{T} 6 \sim 30 \mathrm{~km} \\
\text { downstream }\end{array}$ & & $\begin{array}{l}1.88 \\
(0.23)\end{array}$ & $\begin{array}{l}33 \\
(4)\end{array}$ & $<0.1$ & $\begin{array}{l}210 \\
(86)\end{array}$ & $\begin{array}{l}58 \\
(44)\end{array}$ & $\begin{array}{l}35 \\
(30)\end{array}$ \\
\hline
\end{tabular}

a) WHO, 1993 and 2006, Guidelines for drinking water quality, 2nd and 3rd editions; b) USEPA, 2002, Drinking water. Risk assessment: Technical background information. (MCL values used); c) Long term values, adapted from Fipps, 1996; d) Macklin et al., 1996; e) Simón et al., 1999; f) Bird et al., 2008; g) Mayes et al., 2011. 
Table 4. Examples of floodplain soils and sediment concentrations following tailings dam spills.

\begin{tabular}{|c|c|c|c|c|}
\hline Incident/area & $\mathrm{Cd}(\mathrm{mg} / \mathrm{kg})$ & $\mathrm{Cu}(\mathrm{mg} / \mathrm{kg})$ & $\mathrm{Pb}(\mathrm{mg} / \mathrm{kg})$ & $\mathrm{Zn}(\mathrm{mg} / \mathrm{kg})$ \\
\hline \multicolumn{5}{|l|}{ Dutch soil remediation values ${ }^{\text {a) }}$} \\
\hline Target & 0.8 & 36 & 85 & 140 \\
\hline Intervention & 12 & 190 & 530 & 720 \\
\hline \multicolumn{5}{|l|}{ Chinese legal values $\left.{ }^{b}\right)$} \\
\hline Background threshold & 0.2 & 35 & 35 & 100 \\
\hline $\begin{array}{l}\text { Maximum allowable } \\
\text { concentration }\end{array}$ & 0.6 & 100 & 300 & 250 \\
\hline \multicolumn{5}{|c|}{ Chenzhou, China (25 August, 1985) ${ }^{\mathbf{b})}$ All samples taken August 2002} \\
\hline Background soil, hill $10 \mathrm{~km}$ & 2.08 & 25.95 & 60.49 & 140.48 \\
\hline from mine & $(1.70-2.34)$ & $(22.34-30.66)$ & $(42.17-76.82)$ & $(118.97-184.34)$ \\
\hline Remediated soil, $9.5 \mathrm{~km}$ from & 2.7 & 72.18 & 321.11 & 416.61 \\
\hline mine & $(2.25-3.08)$ & $(53.64-88.18)$ & $\begin{array}{l}(154.47- \\
658.08)\end{array}$ & $(295.87-512.09)$ \\
\hline Unremediated soil, $8 \mathrm{~km}$ from & 7.57 & 135.83 & 1088.3 & 1000.71 \\
\hline mine & $(3.50-11.07)$ & $\begin{array}{l}(110.08- \\
148.95)\end{array}$ & $\begin{array}{l}(852.12- \\
1,443.73)\end{array}$ & $\begin{array}{l}(529.60- \\
1,251.59)\end{array}$ \\
\hline \multicolumn{5}{|c|}{ Porco, Bolivia (August and September 1996) ${ }^{\mathrm{c})}$} \\
\hline \multicolumn{5}{|c|}{ Rio Pilcomayo channel sediments and tailings effluent (1998) } \\
\hline Upstream of Río Pilaya $(\mathrm{n}=6)$ & 62 & 490 & 960 & 8200 \\
\hline & $(6.9-190)$ & $(88-1,400)$ & $(230-1,700)$ & $(1,800-10,000)$ \\
\hline Downstream of Río Pilaya $(\mathrm{n}=$ & $<0.5$ & 14 & 21 & 130 \\
\hline & $(<0.5-0.6)$ & $(11-17)$ & $(20-22)$ & $(9-170)$ \\
\hline \multicolumn{5}{|l|}{ Historic alluvium } \\
\hline Upstream of Río Pilaya $(\mathrm{n}=8)$ & 6 & 95 & 480 & 2000 \\
\hline & $(<0.5-14)$ & $(13-180)$ & $(11-1200)$ & $(93-4800)$ \\
\hline Downstream of Río Pilaya (n = & $<0.5$ & 14 & 13 & 85 \\
\hline & $(<0.5-0.5)$ & $(9-20)$ & $(6-16)$ & $(41-110)$ \\
\hline Pre-mining alluvium $(\mathrm{n}=8)$ & $<0.5$ & $<0.5$ & & 84 \\
\hline & $(<0.5-0.5)$ & $(<0.5-0.5)$ & $(4-28)$ & $(39-130)$ \\
\hline \multicolumn{5}{|l|}{ Aznalcóllar, Spain (April 1998) } \\
\hline \multicolumn{5}{|c|}{ Rio Guadiamar post-cleanup alluvium (January and May 99) } \\
\hline \multirow[t]{2}{*}{$\sim 3 \mathrm{~km}$ downstream $(\mathrm{n}=37)$} & 4.7 & 260 & 990 & 1200 \\
\hline & $(0.5-12)$ & $(17-490)$ & $(50-2,700)$ & $(140-4,600)$ \\
\hline \multirow[t]{2}{*}{$\sim 23 \mathrm{~km}$ downstream $(\mathrm{n}=11)$} & 2.50 & 150 & 300 & 670 \\
\hline & $(<0.1-6.9)$ & $(28-300)$ & $(66-750)$ & $(190-1,800)$ \\
\hline Río Guadiamar suspended & 1.9 & 52 & 190 & 600 \\
\hline sediment (October 1999 flood) ${ }^{\mathrm{e}}$ & & & & \\
\hline \multicolumn{5}{|l|}{ Pre-spill alluvium } \\
\hline \multirow[t]{2}{*}{ Pre-spill alluvium $(\mathrm{n}=17)$} & 0.1 & 78 & 140 & 220 \\
\hline & $(0.1-2.6)$ & $(9.6$ & $(18-$ & $(70-900)$ \\
\hline \multicolumn{5}{|c|}{ Tailings and previous studies on the Rio Guadiamar } \\
\hline \multirow[t]{2}{*}{ Tailings $(\mathrm{n}=11)$} & & $950-3,000$ & $3,700-12,000$ & $3,700-23,000$ \\
\hline & $(12-76)$ & $\begin{array}{l}(1,600) \\
760\end{array}$ & $\begin{array}{l}(8,500) \\
280\end{array}$ & $\begin{array}{l}(7,400) \\
4,670\end{array}$ \\
\hline \multirow{2}{*}{ Alluvium $(1990)^{\mathrm{h}}(\mathrm{n}=3)$} & $\begin{array}{l}\text { n.r. } \\
9.5\end{array}$ & 649 & $\begin{array}{l}280 \\
76\end{array}$ & 2,690 \\
\hline & $(4.72-13.1)$ & $(90.4-1,340)$ & $(35.4-126)$ & $(948-4,200)$ \\
\hline \multirow[t]{2}{*}{ Alluvium $(1983)^{\mathrm{f}}(\mathrm{n}=8)$} & 6.1 & 556 & 473 & 2,043 \\
\hline & $(0.7-10.0)$ & $(24-1,409)$ & $(22-1,212)$ & $(68-5,204)$ \\
\hline \multicolumn{5}{|l|}{ Aurul, Romania (January 2000) ${ }^{\mathrm{i})}$} \\
\hline \multicolumn{5}{|l|}{ River Lapuş channel sediment } \\
\hline July $2000(\mathrm{n}=2)$ & 4.47 and 6.4 & 92 and 200 & 120 and 230 & 400 and 1,100 \\
\hline \multicolumn{5}{|l|}{ River Someş channel sediment } \\
\hline \multirow[t]{2}{*}{ July $2000(n=8)$} & 7.4 & 120 & 70 & 1,100 \\
\hline & $(1.2-17)$ & $(12-360)$ & $(28-120)$ & $(64-3200)$ \\
\hline River Lapuş floodplain sediment & & & & \\
\hline July $2000(n=2)$ & 3.2 and 3.2 & 72 and 100 & 100 and 220 & 520 and 640 \\
\hline
\end{tabular}




\begin{tabular}{|c|c|c|c|c|}
\hline $\begin{array}{l}\text { River Someş floodplain sediment } \\
\text { July } 2000(\mathrm{n}=8)\end{array}$ & $\begin{array}{l}2.3 \\
(0.8-4)\end{array}$ & $\begin{array}{l}56 \\
(20-160)\end{array}$ & $\begin{array}{l}67 \\
(28-110)\end{array}$ & $\begin{array}{l}260 \\
(84-600)\end{array}$ \\
\hline \multicolumn{5}{|c|}{ Novaț Roșu, Romania (March 2000) j) } \\
\hline July $(2001)$ & $\begin{array}{l}0.43 \\
(1.3-19)\end{array}$ & $\begin{array}{l}250 \\
(87-1,000)\end{array}$ & $\begin{array}{l}200 \\
(53-930)\end{array}$ & $\begin{array}{l}1300 \\
(390-5,600)\end{array}$ \\
\hline July (2003) & $\begin{array}{l}3.4 \\
(2-6.2)\end{array}$ & $\begin{array}{l}320 \\
(190-540)\end{array}$ & $\begin{array}{l}270 \\
(180-470)\end{array}$ & $\begin{array}{l}750 \\
(540-1,300)\end{array}$ \\
\hline \multicolumn{5}{|c|}{ Rivers Vaser and Vişeu channel sediments } \\
\hline July $2000(n=8)$ & $\begin{array}{l}3.8 \\
(1.6-5.6)\end{array}$ & $\begin{array}{l}300 \\
(100-520)\end{array}$ & $\begin{array}{l}180 \\
(100-270)\end{array}$ & $\begin{array}{l}1,000 \\
(280-1,400)\end{array}$ \\
\hline July $2001(n=9)$ & $\begin{array}{l}1 \\
(0.6-1.6)\end{array}$ & $\begin{array}{l}75 \\
(44-120)\end{array}$ & $\begin{array}{l}21 \\
(14-34)\end{array}$ & $\begin{array}{l}320 \\
(220-410)\end{array}$ \\
\hline July $2002(\mathrm{n}=9)$ & $\begin{array}{l}2.2 \\
(0.5-4)\end{array}$ & $\begin{array}{l}170 \\
(30-330)\end{array}$ & $\begin{array}{l}100 \\
(25-200)\end{array}$ & $\begin{array}{l}430 \\
(96-800)\end{array}$ \\
\hline July $2003(n=12)$ & $\begin{array}{l}2.8 \\
(1.2-6.3)\end{array}$ & $\begin{array}{l}220 \\
(81-540)\end{array}$ & $\begin{array}{l}140 \\
(45-300)\end{array}$ & $\begin{array}{l}570 \\
(270-1,200)\end{array}$ \\
\hline \multicolumn{5}{|l|}{$\begin{array}{l}\text { River Vaser and Vişeu } \\
\text { floodplain sediment }\end{array}$} \\
\hline July $2000(n=7)$ & $\begin{array}{l}3.9 \\
(1.2-10)\end{array}$ & $\begin{array}{l}250 \\
(32-760) \\
\end{array}$ & $\begin{array}{l}310 \\
(44-920) \\
\end{array}$ & $\begin{array}{l}1,100 \\
(100-3,200)\end{array}$ \\
\hline \multicolumn{5}{|c|}{ Abaróa, Bolivia (February 2003) } \\
\hline Floodplain soils $(n=14)$ & n.r. & n.r. & $\begin{array}{l}94 \\
(27-241)\end{array}$ & $\begin{array}{l}310 \\
(103-643)\end{array}$ \\
\hline Tailings & & & & \\
\hline Abaróa Mine $(\mathrm{n}=3)$ & n.r. & n.r. & $\begin{array}{l}85 \\
(63-114)\end{array}$ & $\begin{array}{l}216 \\
(131-279)\end{array}$ \\
\hline $\begin{array}{l}\text { Chilcobija Mine }(\mathrm{n}=2) \\
\text { Rio Chilco channel sediment }\end{array}$ & n.r. & n.r. & 146 and 179 & 72 and 107 \\
\hline $\begin{array}{l}\text { Downstream of Abaróa Mine ( } \mathrm{n} \\
=5 \text { ) }\end{array}$ & n.r. & n.r. & $\begin{array}{l}466 \\
(330-610)\end{array}$ & $\begin{array}{l}1105 \\
(587-1515)\end{array}$ \\
\hline $\begin{array}{l}\text { Upstream of Rio Machocuya ( } \mathrm{n} \\
=4 \text { ) }\end{array}$ & n.r. & n.r. & $\begin{array}{l}80 \\
(12-206)\end{array}$ & $\begin{array}{l}245 \\
(76-458)\end{array}$ \\
\hline \multicolumn{5}{|c|}{ Kolontar, Hungary (October 4, 2010) } \\
\hline & As & $\mathrm{Mn}$ & Mo & $\mathrm{V}$ \\
\hline Reference samples $(n=18)$ & 3.75 & 356.8 & 6.6 & 31.7 \\
\hline $\begin{array}{l}\text { Fly ash from impoundment wall } \\
(\mathrm{n}=9)\end{array}$ & 29.9 & 182.0 & 53.0 & 185.6 \\
\hline $\begin{array}{l}\text { Sediment immediately adjacent } \\
\text { to dam breech }(n=9)\end{array}$ & 78.5 & 2,565 & 14.4 & 891.2 \\
\hline $\begin{array}{l}\text { Kolontar village } \sim 3 \text { jn } \\
\text { downstream }\end{array}$ & 51.9 & 1,606 & 7.3 & 458.9 \\
\hline $\mathrm{T} 4 \sim 10 \mathrm{~km}$ downstream & 50.8 & 1,447 & 8.7 & 433.7 \\
\hline T6 30 km downstream & 54.9 & 1,870 & 9.8 & 562.4 \\
\hline
\end{tabular}

Mean concentration with range in brackets; $\mathrm{n}=$ number of samples; n.d. $=$ non-detectable; $n . r .=$ not reported; s.d. = standard deviation.

a) Macklin et al., 2006; b) Liu et al., 2005; c) Macklin et al., 1996; d) Hudson-Edwards et al., 2003;

e) Turner et al., 2002; f) Gonzalez et al., 1990; g) Ramos et al., 1994; h) Martin et al., 2002; i)

Macklin et al., 2003; j) Bird et al., 2008; k) Villarroel et al., 2006; 1) Mayes et al., 2011. 


\section{Figure Captions}

Figure 1. Photo and photomicrograph of tailings. (a) grey sulphide tailings in stream flowing through town of Huanuni, Bolivia; (b) Bolivian mine tailings primary phases undergoing cementation by secondary jarosite following three years of column leaching experiments (described in Kossoff et al., 2012b); (c) Mining area at Berkeley, Montana, USA. Grey tailings are stored in the tailings pond shown to the left of the dark-coloured Berkley Pit. (Image courtesy of NASA Earth Observatory).

Figure 2. Schematic illustrations of upstream, downstream and centreline sequentially raised tailings dams (redrawn after Vick, 1983).

Figure 3. Good and poor practice in construction of upstream tailings dams (redrawn after Martin and McRoberts, 1999, used with permission). The phreatic surface must be well below the dam wall to reduce susceptibility to liquefaction under severe seismic events.

Figure 4. Photographs of tailings impoundment failures and effects. (a) and (b) Views downstream of the effects of the tailings dam failure at Stava, North Italy, 1985. Used with permission from the Archive Stava 1985 Onlus Foundation - www.stava1985.it. (c) Red mud spill at Akja, Hungary, 2010. Image used courtesy of NASA.

Figure 5. A portion of the Pailaviri tailings deposit which lies within the Huayna Mayu watershed, Bolivia. The Pailaviri tailings are less than $100 \mathrm{~m}$ from Huayna Mayu, which drains to the Ribera de la Vera Cruz, less than $2 \mathrm{~km}$ from the location pictured. Such tailings piles are also highly susceptible to wind transport. From Strosnider et al. (2008), used with permission from W.H. Strosnider. 